Fordham Law School

FLASH: The Fordham Law Archive of Scholarship and History

Faculty Scholarship

2021

\title{
Balancing Independence and Accountability: Proposals to Reform Special Counsel Investigations
}

\author{
Lawrence Keating \\ Fordham University School of Law \\ Steven Still \\ Fordham University School of Law \\ Brittany Thomas \\ Fordham University School of Law \\ Samuel Wechsler \\ Fordham University School of Law
}

Follow this and additional works at: https://ir.lawnet.fordham.edu/faculty_scholarship

Part of the Constitutional Law Commons, and the Law and Politics Commons

\section{Recommended Citation}

Lawrence Keating, Steven Still, Brittany Thomas, and Samuel Wechsler, Balancing Independence and Accountability: Proposals to Reform Special Counsel Investigations, January (2021)

Available at: https://ir.lawnet.fordham.edu/faculty_scholarship/1111

This Article is brought to you for free and open access by FLASH: The Fordham Law Archive of Scholarship and History. It has been accepted for inclusion in Faculty Scholarship by an authorized administrator of FLASH: The Fordham Law Archive of Scholarship and History. For more information, please contact tmelnick@law.fordham.edu. 


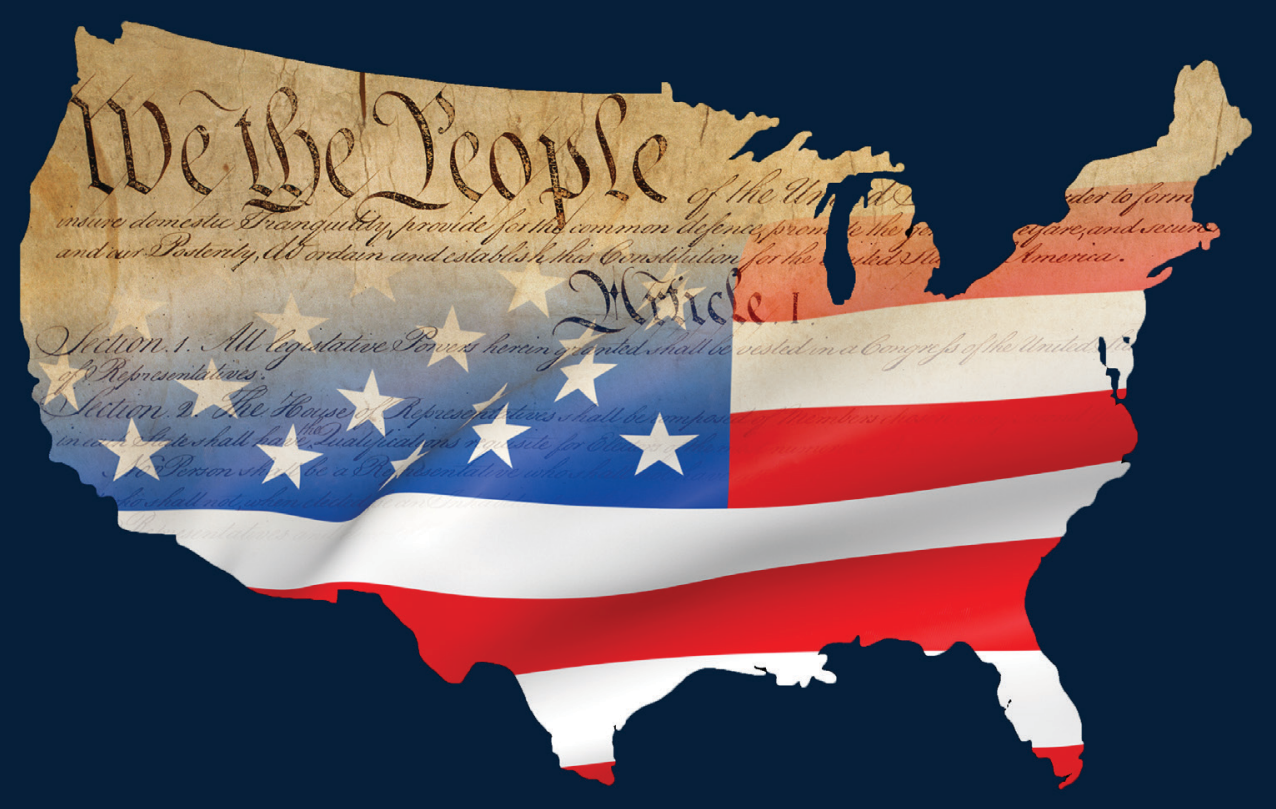

\section{Balancing Independence and Accountability: Proposals to Reform Special Counsel Investigations}

Democracy and the Constitution Clinic

Fordham University School of Law

Lawrence Keating, Steven Still, Brittany Thomas, \& Samuel Wechsler

January 2021 


\title{
Balancing Independence and Accountability: Proposals to Reform Special Counsel Investigations
}

\author{
Democracy and the Constitution Clinic \\ Fordham University School of Law
}

\section{Lawrence Keating, Steven Still, Brittany Thomas, \& Samuel Wechsler}

January 2021

This report was researched and written during the 2019-2020 academic year by students in Fordham Law School's Democracy and the Constitution Clinic, where students developed non-partisan recommendations to strengthen the nation's institutions and its democracy. The clinic was supervised by Professor and Dean Emeritus John D. Feerick and Visiting Clinical Professor John Rogan.

\section{Acknowledgments:}

We are grateful to the individuals who generously took time to share their general views and knowledge with us: Professor Jed H. Shugerman, Representative Thomas Suozzi, Dean William M. Treanor, Mark H. Tuohey, Esq., and Jesse Wegman, Esq.

This report greatly benefited from Gail McDonald's research guidance and Flora Donovan's editing assistance. Judith Rew and Robert Yasharian designed the report. 


\section{Table of Contents}

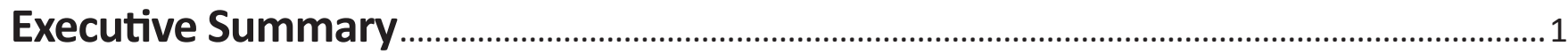

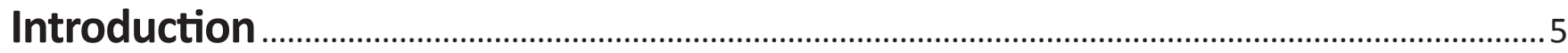

I. History

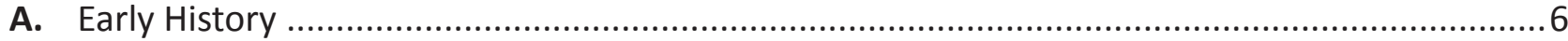

B. Watergate Through the Ethics in Government Act..............................................................10

C. Post-Watergate Investigations under the Ethics in Government Act.......................................12

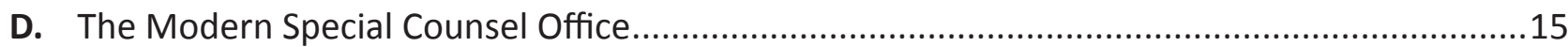

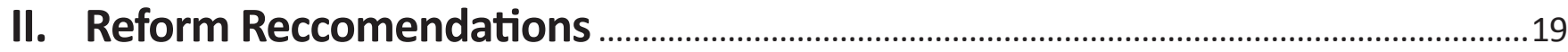

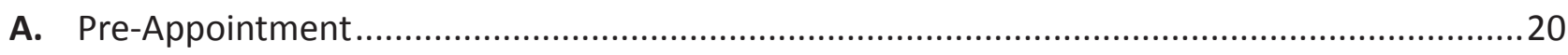

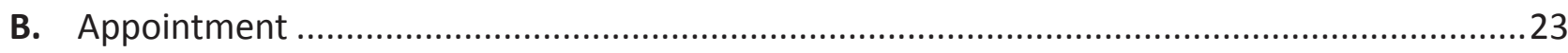

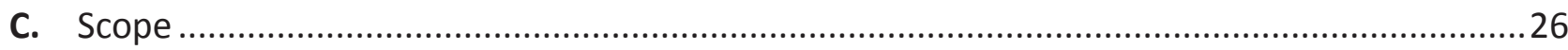

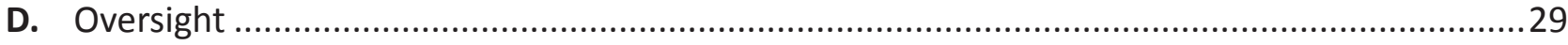

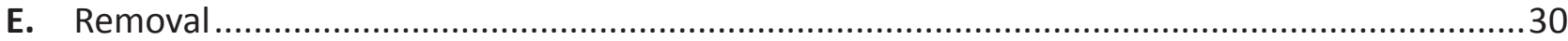

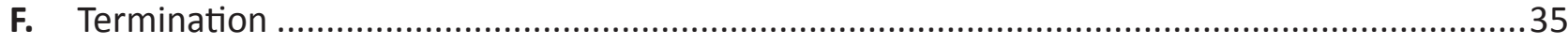

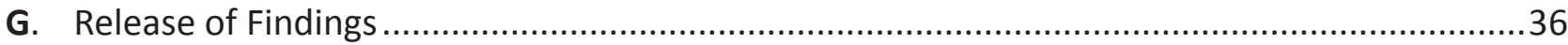

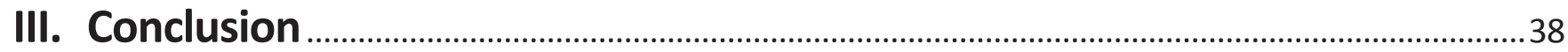




\section{Executive Summary}

The Department of Justice ("DOJ") oversees countless criminal and civil investigations on behalf of the federal government. Perhaps the most contentious and fraught are investigations that implicate the president or other high-ranking executive branch officials. As the president is the most senior official charged with ensuring that the "laws be faithfully executed," these situations almost invariably create actual or perceived conflicts of interest for investigators. When the highest levels of the executive branch are compromised, political motivations can impede meritorious investigations, especially when DOJ personnel are implicated. If high ranking prosecutors or even the attorney general are suspected of illegality, it is inapposite to the notion of an impartial investigation to allow them to influence the process.

To protect the integrity of investigations into high-level officials, the executive branch utilizes special counsels. These individuals are experienced attorneys, brought in from outside the government and empowered with authority and resources to conduct specific investigations. Procedures related to special counsel investigations evolved over time. The title of the attorneys who conducted the investigations also changed-from special prosecutor to independent counsel to special counsel. Initially, the process for conducting the investigations was informal. Presidents would appoint special prosecutors largely as a show of good faith and to demonstrate that they were taking allegations of corruption seriously. Without formal standards, there was nothing to prevent these investigations from being cut short if the prosecutor proved too effective at rooting out misconduct within the government.

President Richard Nixon's firing in 1973 of the special prosecutor investigating the Watergate scandal prompted Congress to pass a law outlining the rules and procedures for the investigations. The Ethics in Government Act allowed the attorney general to request a Special Division of federal judges to appoint an independent counsel to conduct an investigation. The DOJ utilized independent counsels to carry out several high-profile investigations, including the inquiry into the Iran-Contra Affair, which involved the Reagan administration's use of proceeds from arms sales to Iran to fund rebels opposing Nicaragua's socialist government. When the constitutionality of the Ethics in Government Act's independent counsel provisions was challenged in Morrison v. Olson, the Supreme Court upheld the statute as valid under the Appointments Clause.

After former federal judge Kenneth Starr's independent counsel investigation into President William Clinton reached far beyond its original focus, many in Congress came to believe the independent counsel law did not place sufficient checks on investigators. As a result, Congress allowed the Ethics in Government Act to expire and the DOJ promulgated internal regulations

\section{Democracy Clinic}


granting the attorney general authority to appoint special prosecutors, renamed "special counsels."

The most recent investigation under these regulations was Special Counsel Robert Mueller's inquiry into Russian meddling in the 2016 presidential election. The investigation, which faced constant public criticism from President Donald Trump, produced indictments of several Trump campaign officials. But the extensive report issued by Mueller's office stated that there was insufficient evidence to support criminal charges based on the Trump campaign coordinating with the Russian efforts against the election. Additionally, the report declined to reach a conclusion on whether Trump committed obstruction of justice by attempting to thwart Mueller's probe. Mueller submitted his report to Attorney General William Barr in accordance with DOJ regulations. Several weeks later, the DOJ released a redacted version of the report to the public. Barr released a summary of the report just days after receiving it that many, including Mueller, felt mischaracterized the report to make the investigation's findings appear more favorable to Trump.

The Ethics in Government Act's independent counsel provisions and the DOJ's special counsel regulation have both faced criticism. Under the Ethics in Government Act, an independent counsel had such significant autonomy that lawmakers feared an unaccountable "runaway prosecutor." By contrast, observers of the Mueller investigation felt that the investigation was handcuffed, particularly in regards to the reporting and public release of its findings.

Our recommendations for improving special counsel investigations seek to draw on elements of both systems to balance the competing interests of prosecutorial independence and accountability. We conclude that the country would be best served through a return to legislation codifying specific procedures encompassing all phases of a special counsel investigation.

1. Pre-Appointment: The attorney general should be responsible for conducting a preliminary investigation to determine if allegations are sufficient to warrant appointment of a special counsel. The DOJ's Office of Professional Responsibility should have an affirmative responsibility to continuously evaluate whether the attorney general has potential conflicts of interest that would require an ethics consultation. To prevent the attorney general from failing to appoint a special counsel when necessary, we recommend two measures. First, the attorney general should be required to appoint a special counsel whenever certain high-ranking executive officers, such as the president, vice president, and Cabinet secretaries, are suspected of committing a crime or become the "subject" of an investigation. Second, Congress should be able to petition the attorney general to evaluate whether a special counsel investigation is necessary.

2. Appointment: A special counsel should be appointed by a Special Division of the federal judiciary chosen by the chief justice of the United States. The Special Division's

\section{Democracy Clinic}


appointment should be based on a recommendation from the attorney general. If the Special Division rejects the attorney general's proposed special counsel, the attorney general should be able to propose another candidate.

3. Scope: The scope of a special counsel's investigation should be subject to approval from the Special Division judges. At the same time that the Special Division approved a special counsel's appointment, it would provide the special counsel with the scope of the investigation. Changes to the scope would require approval from the Special Division. The attorney general could refer matters in the special counsel's ambit back to the DOJ, but the Special Division could reverse any of those referrals. The special counsel would have discretion to refer matters out of his or her office to the DOJ. This oversight of the special counsel's scope would prevent overly expansive investigations, while protecting against the possibility that the attorney general might undermine the investigation by limiting its range.

4. Oversight: The attorney general should have primary oversight of special counsel investigations because the attorney general is better positioned than the courts or Congress to make decisions about federal criminal investigations. To prevent interference, the attorney general should be required to report to Congress whenever he or she prevents the special counsel from taking any investigative or prosecutorial step. Additionally, the special counsel's budget should be periodically reported to Congress.

5. Removal: Although the power to remove a special counsel should be exercised sparingly, it has historically been vested and should remain with the attorney general. But removal must be "for cause," as defined in the current DOJ special counsel regulations. The law should require the attorney general to submit a petition to remove a special counsel to the Special Division for review to ensure that the "for cause" standard is met.

6. Termination: When an investigation has reached a conclusion, the special counsel or attorney general should have authority to formally terminate the investigation. The Special Division should review a termination decision by the attorney general, but should only withhold approval in extreme circumstances, such as when it is clear that the attorney general is ending the investigation to obstruct it. Although it is important to prevent "runaway" investigations, it is impractical to impose formal timelines or end dates on investigations.

7. Release of Findings: At the close of an investigation, a special counsel should submit a report to Congress on the investigation's findings. The report should make a clear statement as to whether the special counsel believes the subjects of the investigation acted unlawfully, even when evaluating the president's conduct. Congress should make

\section{Democracy Clinic}


public as much of the report as possible. Ensuring that the special counsel's findings are released with minimal interference recognizes that members of the executive branch are accountable to Congress and the public. 


\section{Introduction}

At the Constitutional Convention, the framers vested power in the executive branch to ensure the faithful execution of the laws, but they did not fully address how to handle the conflicts interest that might emerge when the laws needed to be enforced against executive branch officials. Over time, it became apparent that further protection was necessary to ensure that the laws were applied equally, and, in 1875, the first special counsel (then called a "special prosecutor") was appointed to conduct an investigation of executive branch officials. Special counsel investigations have since become an indispensable tool for rooting out corruption and restoring the public's confidence in government.

But special counsel investigations and the rules for conducting them have not been without flaws. At times, the investigations have suffered deliberate attempts, including by the president, to undermine them. Other times, special counsels have drawn criticism for conducting excessively costly investigations without appropriate restraint.

This report examines past special counsel investigations and recommends a law with procedures for future investigations that achieves a balance between independence and accountability. The report begins with a history of significant previous special counsel investigations. Next, the report analyzes each phase of a special counsel investigation, discussing the approaches under the Ethics in Government Act and the current Department of Justice ("DOJ") regulations and presenting our recommendations for reforming the rules to help ensure that the special counsel is protected from undue influence, but not over-empowered.

\section{History}

Special counsel investigations have scrutinized the executive branch since 1875 . The investigation of the Watergate scandal during the Nixon administration was a significant force in ending Nixon's presidency and led Congress to pass a law governing future investigations. But the procedures in that law were ultimately abandoned by Congress after the independent counsel investigation during the Clinton administration raised concerns that the law gave investigators too much autonomy. The DOJ subsequently created regulations for conducting the investigations, and those regulations guided the most recent special counsel investigation: Robert Mueller's probe of Russian meddling in the 2016 presidential election.

\section{Democracy Clinic}




\section{A. Early History}

The early history of special counsel investigations began in 1875 during President Ulysses S. Grant's administration and continued into Harry S. Truman's presidency in the 1950s.

\section{President Ulysses S. Grant (Whiskey Ring Scandal)}

In 1875, Secretary of the Treasury Benjamin Bristow began an anti-corruption campaign that resulted in his agents uncovering "whiskey rings" in cities throughout the United States. ${ }^{1}$ Government officials tasked with collecting taxes and whiskey producers underreported the production of whiskey in order to pay less federal tax and divided excess financial gains among themselves. ${ }^{2}$ This fraud cost the federal government millions of dollars in lost revenue. ${ }^{3}$

In May 1875, President Ulysses S. Grant, then in his second term, appointed former Senator John B. Henderson, a man known for his political independence, to prosecute the whiskey ring participants. ${ }^{4}$ Henderson was the first special prosecutor appointed to investigate individuals within the executive branch. ${ }^{5}$ His investigation quickly began to implicate high-level executive branch officials, including Revenue Supervisor John McDonald. ${ }^{6}$ However, when Orville Babcock, President Grant's close friend and private secretary, became a target, Grant found scrutiny of Babcock to be "unwarranted" and suspected that political enemies were using it to "further discredit the Grant administration."7 As a result, Grant fired Henderson in December 1875 , only seven months into his investigation. ${ }^{8}$ Grant easily removed Henderson. There were no laws or regulations that limited his discretion; the special prosecutor served purely at the pleasure of the president. ${ }^{9}$ Henderson's removal did not put an end to Grant's troubles. Secretary Bristow continued investigating, and, although Babcock was acquitted, others, including McDonald and his assistant, were successfully prosecuted. ${ }^{10}$

\footnotetext{
${ }^{1}$ See Gerald S. Greenberg, Historical Encyclopedia of U.S. Independent Counsel InVestigations 163 (2000); Jennifer Rose Hopper, Reexamining the Nineteenth-Century Presidency and Partisan Press: The Case of President Grant and the Whiskey Ring Scandal, 42 Soc. SCI. HIST. 109, 115 (2018).

${ }^{2}$ Hopper, supra note 1 , at 115.

${ }^{3}$ Id.

${ }^{4}$ GREENBERG, supra note 1, at 147, 163.

${ }^{5} / d$. at 147.

${ }^{6} / d$. at 163.

${ }^{7}$ Id.

${ }^{8} / d$.

${ }^{9} / d$.

${ }^{10} / d$.
} 


\section{President Theodore Roosevelt (Oregon Land Fraud Scandal \& Post Office Scandal)}

During President Theodore Roosevelt's tenure in office, special prosecutors were appointed for two separate investigations: the Oregon Land Fraud Scandal and the Post Office Scandal. The land fraud scandal centered around a stretch of public land from Portland to California that the federal government and state of Oregon had granted to railroad companies. ${ }^{11}$ Congress had passed a law allowing land around the new railroad to be sold to homestead farmers for very low prices to stimulate settlement and growth. ${ }^{12}$ However, the land was not well-suited to homestead farming; it was best adapted to ventures like raising cattle and lumbering. ${ }^{13}$ So, state and federal officials, including members of the Department of the Interior, conspired to fraudulently sell the land to people and companies seeking to use it for commercial purposes. ${ }^{14}$

U.S. Attorney John H. Hall was initially tasked with investigating the scheme. Other prosecutors had expedited the fraudulent land claims, but Hall did not. ${ }^{15}$ As a result, in 1903, Attorney General Philander Knox appointed a special prosecutor, Francis J. Heney, to take over the investigation. ${ }^{16}$ Throughout the investigation, Heney's willingness to aggressively pursue those in power led some to push for his removal. Despite the pressure, Roosevelt continued to support Heney's independence. ${ }^{17}$ Heney's investigation lasted seven years and culminated in convictions against several individuals, including U.S. Attorney Hall, Congressman Binger Hermann, Congressman John N. Williamson, and Senator John H. Mitchell. ${ }^{18}$

President Roosevelt appointed another special prosecutor, Charles J. Bonaparte, to investigate corruption in the Post Office. ${ }^{19}$ Bonaparte's appointment came in 1903 after Assistant Attorney General John N. Tyner's resignation. Tyner had been charged with destroying documents linked to the investigation. ${ }^{20}$ After concluding his investigation, Bonaparte suggested reforms to the Post Office and led prosecutions against Tyner, Postmaster General Charles Emory Smith, and First Assistant Postmaster General Perry S. Heath. ${ }^{21}$ Though the prosecutions were mostly unsuccessful, their initiation alone, in combination with the adoption of Bonaparte's

\footnotetext{
${ }^{11}$ Michael C. Blumm \& Tim Wigington, The Oregon \& California Railroad Grant Lands' Sordid Past, Contentious Present, and Uncertain Future: A Century of Conflict, 40 B.C. Env'T AfF. L. Rev. 8, 12 (2013).

12 John Messing, Public Lands, Politics, and Progressives: The Oregon Land Fraud Trials, 1903-1910, 35 PAC. HIST. REV. 35, 35 (1966).

13 Id. at 36.

${ }^{14}$ Id. at 35; Giancarlo Panagia, The Political History of Federal Land Exchanges, EleCtronic GreEN J., no. 28, Spring 2009.

${ }^{15}$ GreenberG, supra note 1, at 164-65; Messing, supra note 12, at 43-44.

${ }^{16}$ GREENBERG, supra note 1 , at 165.

17 Id. at 290.

${ }^{18}$ Id. at 165-66.

19 Id. at 290.

${ }^{20} / d$. at 29, 290-91.

${ }^{21}$ Id.
}

\section{Democracy Clinic}


recommendations, led to substantive changes to the formerly corrupt agency. ${ }^{22}$ In 1906 , Roosevelt appointed Bonaparte to be attorney general. ${ }^{23}$

Although no statutes or regulations limited Roosevelt's authority over the special prosecutors appointed during his term, he supported their efforts and allowed them the independence they needed to effectively carry out their work. ${ }^{24}$ Roosevelt's own initiatives had spawned the investigations, but he was a passionate advocate for government reform. ${ }^{25}$ As a result, these inquiries did not evoke the same apparent ire as other investigations where the president's actions, personal life, or close associates came under suspicion.

\section{President Calvin Coolidge (Teapot Dome Scandal)}

The misconduct in the Teapot Dome Scandal took place during President Warren Harding's administration, but the responsibility to investigate it fell to President Calvin Coolidge, who assumed office after Harding's death in $1923 .{ }^{26}$ In the early 1900s, the Navy Department controlled certain oil reserves. ${ }^{27}$ In 1921, at the behest of Interior Secretary Albert Fall, President Harding issued an executive order transferring two vast naval oil reserves, Teapot Dome and Elk Hills, from the Navy to the Interior Department. ${ }^{28}$ Once the transfer was complete, Fall covertly leased both to oil companies. ${ }^{29}$ When President Coolidge took office, the transactions had become a scandal. Media attention, congressional hearings, and accusations of a DOJ cover-up forced Coolidge to take action. ${ }^{30}$ He appointed two special prosecutors, one from each major political party. Coolidge nominated Republican lawyer Owen Roberts and former Democratic Senator Atlee Pomerene for Senate confirmation. ${ }^{31}$ Pomerene and Roberts were confirmed in February 1924, the only time the Senate has confirmed any special prosecutor. ${ }^{32}$ The investigation led to the conviction of Secretary Fall for bribery and the cancelation of the leases he brokered. ${ }^{33}$ During the investigation, a special committee found that Attorney General Harry Daugherty had not adequately handled the case, and he was forced to resign. ${ }^{34}$

22 See id. at 28-29.

23 Id.

${ }^{24}$ See id. at 291.

${ }^{25} \mathrm{Id}$. at 289-90.

${ }^{26}$ Donald C. Smaltz, The Independent Counsel: A View from Inside, 86 GEO. L.J. 2307, 2314 (1998).

27 GREENBERG, supra note 1, at 75 .

${ }^{28}$ Id. at 87, 158-59.

${ }^{29}$ Smaltz, supra note 26, at 2315.

${ }^{30}$ See id.

${ }^{31}$ Id. at 2316.

32 GREenBERG, supra note 1, at 276.

33 Id.; Gary D. Libecap, The Political Allocation of Mineral Rights: A Re-Evaluation of Teapot, 44 J. EcoN. HIST. 381 , 382 (1984).

${ }^{34}$ GREENBERG, supra note 1, at 336.

\section{Democracy Clinic}


The Teapot Dome Scandal demonstrated that public outcry and fear of congressional action can force the executive branch's hand. The scandal also showed that congressional involvement in the appointment of special prosecutors can improve Congress's confidence in an investigation and prevent it from taking more drastic actions to investigate. Additionally, congressional confirmation forced Coolidge to carefully consider his nominees. In fact, his first two nominees were not confirmed after their oil industry connections were revealed. ${ }^{35}$

\section{President Harry S. Truman (Bureau of Internal Revenue Scandal)}

Three decades after the Teapot Dome Scandal, President Harry Truman appointed a special prosecutor to investigate allegations of misconduct within the Bureau of Internal Revenue. Before there was any suggestion of appointing a special prosecutor, an in-depth congressional investigation, a series of prosecutions and convictions, and personnel changes were already underway. ${ }^{36}$ To appease Congress, the public, and the media, Truman believed it was necessary to appoint a special prosecutor to investigate corruption within his administration. ${ }^{37}$ Initially, Truman planned to entrust the investigation to a three-person team of special prosecutors, consisting of Alger Hiss, clergyman Daniel Poling, and Judge Thomas F. Murphy. ${ }^{38}$ This plan quickly fell apart. Murphy withdrew and, soon after, Poling resigned. ${ }^{39}$

Truman then tasked Attorney General J. Howard McGrath with selecting a special prosecutor. In February 1952, McGrath appointed Newbold Morris as the special prosecutor charged with investigating the Bureau of Internal Revenue. ${ }^{40}$ Morris previously worked with New York Mayor Fiorello La Guardia and was known for being "an irrepressible reformer." 41 Despite this reputation, Morris had a brief and ineffective tenure as a special prosecutor. ${ }^{42}$ After Congress denied him subpoena powers, Morris searched for alternative methods to conduct his investigation. ${ }^{43} \mathrm{He}$ decided to create a questionnaire that would collect detailed information about the income and spending of federal government employees to determine whether their spending matched their income. ${ }^{44}$ But Morris drew the ire of Attorney General McGrath by sending him 596 copies of the questionnaire to be distributed among DOJ employees. ${ }^{45}$

${ }^{35}$ Id. at 276.

36 Id. at 334.

${ }^{37}$ Id.; see also Smaltz, supra note 26, at 2316.

${ }^{38}$ GREENBERG, supra note 1 , at 232.

${ }^{39}$ Id.

${ }^{40} / d$. at 231-32.

${ }^{41}$ Id. at 232; The Administration: Exits and Entrances, TIME MAG. (Apr. 14, 1952), http://content.time.com/time/magazine/article/0,9171,857104,00.html.

${ }^{42}$ GREENBERG, supra note 1 , at 232-33.

43 Id.

${ }^{44}$ Id. at 232-33.

${ }^{45}$ Id. at 233.

\section{Democracy Clinic}


McGrath objected to Morris's "aggressive approach" and fired him in April $1952 .{ }^{46}$ In response to Morris's dismal, President Truman fired McGrath. ${ }^{47}$ Though another special prosecutor for this matter was never appointed, those responsible for corruption within the Bureau of Internal Revenue were brought to justice through standard prosecutions. ${ }^{48}$

\section{B. Watergate Through the Ethics in Government Act}

The special prosecutor investigation into the Watergate Scandal reached previously unseen levels of prominence and importance. Shortly after Elliot Richardson's appointment as attorney general in 1973, he named Archibald Cox as special prosecutor to investigate the spiraling Watergate scandal. ${ }^{49}$ Despite White House denials of any involvement in a break-in at the Democratic National Committee's offices, the investigation into the incident had drawn progressively closer to the Oval Office. ${ }^{50}$ Testimony at congressional hearings had implicated Nixon's top aides and suggested that the White House had deliberately acted to minimize backlash from the investigation. Nixon had responded by asking for the resignation of the attorney general and White House counsel and by nominating Richardson as the new attorney general. ${ }^{51}$ During his confirmation hearings, Richardson had announced that he would appoint a special prosecutor and not interfere with the ensuing investigations. ${ }^{52}$ Cox's appointment soon sparked unprecedented conflict in the executive branch.

The dispute began when former White House Counsel John Dean told prosecutors and Congress that he believed conversations in the Oval Office were being taped. ${ }^{53}$ Following the testimony of Dean and others, the significance of Nixon's recording system became clear. Cox served a subpoena on Nixon for the tapes. When Nixon refused to comply, Cox secured a court order directing him to produce the tapes. Nixon challenged the order, arguing that the tapes were protected by executive privilege. ${ }^{54}$ The U.S. District Court for the District of Columbia

${ }^{46} I d$. at $222,233$.

${ }^{47}$ Id.

48 Id. at 346.

${ }^{49}$ Id. at 286.

50 See Heidi Kitrosser, What If Daniel Ellsberg Hadn't Bothered?, 45 IND. L. ReV. 89, 101-02 (2011). See also McCord Declares That Mrs. Mitchell Was Forcibly Held, N.Y. TIMES (Feb. 19, 1975),

https://www.nytimes.com/1975/02/19/archives/mccord-declares-that-mrs-mitchell-was-forcibly-held-commentfrom.html.

${ }^{51}$ Edward McGlynn Gaffney, Jr., The Principled Resignation of Thomas More, 31 LoY. L.A. L. REV. 63,64 (1997).

52 Id.; Watergate Special Prosecution Force, Watergate Special Prosecution Force Report 172 (1975); see Anthony Ripley, Senate Speedily Confirms Richardson by 82-3 Vote, N.Y. TIMES (May 24, 1973), https://www.nytimes.com/1973/05/24/archives/senate-speedily-confirms-richardson-by-823-voterichardson.html.

53 See Samuel Dash, Congress' Spotlight on the Watergate Hearings, 18 Nova L. REV. 1719, 1732-35 (1994).

54 Watergate Special Prosecution Force, supra, note 52, at 90-92.

\section{Democracy Clinic}


rejected Nixon's argument, and ordered that the tapes be produced or submitted to the court for in camera review. ${ }^{55}$

Instead of complying, Nixon proposed releasing summaries of the tapes to be verified by a chosen senator, and called on Cox to "cease all further attempts to obtain Presidential materials through the courts." 56 Cox refused, and, on October 20, Nixon ordered Richardson to fire him. Rather than carry out the order, Richardson resigned in protest, followed quickly by Deputy Attorney General William Ruckelshaus, in what the press dubbed the "Saturday Night Massacre." The order fell to the next most senior DOJ official, Solicitor General Robert Bork, who, at last, dismissed Cox. ${ }^{57}$ If Nixon experienced any reprieve, it was short-lived. Public outcry was tremendous, and the press demanded the appointment of another special prosecutor. ${ }^{58}$ On November 1, only 12 days after Cox's firing, Bork, with Nixon's approval, appointed Leon Jaworski as special prosecutor to resume the investigation. ${ }^{59}$

In early 1974, Jaworski issued a subpoena for the same tapes that cost Cox his position. This time, under considerable public pressure, Nixon released edited transcripts of a select number of tapes and moved to have the D.C. District Court quash the subpoena. ${ }^{60}$ The district court again rejected Nixon's assertion of executive privilege, and ordered him to comply with Jaworski's subpoena. ${ }^{61}$ The case went directly to the Supreme Court. ${ }^{62}$ The Court's decision in the landmark case, U.S. v. Nixon, written by Chief Justice Warren Burger, considered the limits of executive privilege at length. The Court upheld the district court's ruling, asserting that executive privilege does not allow the president to withhold evidence that is relevant to a criminal proceeding. ${ }^{63}$ The unanimous decision helped define the outer limits of executive privilege.

55 In re Subpoena to Nixon, 360 F. Supp. 1, *14 (D.D.C. 1973), aff'd sub nom. Nixon v. Sirica, 487 F.2d 700 (D.C. Cir. 1973).

56 John M. Crewdson, Richardson Quits Over Order on Cox, N.Y. TIMES (Oct. 21, 1973), https://www.nytimes.com/1973/10/21/archives/richardson-quits-over-order-on-cox-attorney-general-says-hecouldnt.html; Don Bivens, Watergate Inspires After 40 Years, 40 LITIG. 4, 4 (2014).

57 Bivens, supra note 56 , at 5.

${ }^{58}$ Carl Levin \& Elise J. Bean, The Independent Counsel Statute: A Matter of Public Confidence and Constitutional Balance, 16 HofSTRA L. REV. 11, 12-13 (1987).

${ }^{59}$ Anthony Ripley, Jaworski Assumes Office; Bork Praises Prosecutor, N.Y. TIMES (Nov. 6, 1973), https://www.nytimes.com/1973/11/06/archives/jaworski-assumes-office-bork-praises-prosecutor-8-to-beconsulted.html.

${ }^{60}$ United States v. Mitchell, 377 F. Supp. 1326, 1328, 1330 (D.D.C. 1974), aff'd sub nom. United States v. Nixon, 418 U.S. 683 (1974).

${ }^{61}$ Id. at 1331.

${ }^{62}$ See United States v. Nixon, 418 U.S. 683 (1974).

${ }^{63}$ Id. at 713.

\section{Democracy Clinic}


Another Watergate era test of presidential powers came from a lawsuit challenging Cox's firing. ${ }^{64}$ Although Jaworski had already been appointed, the D.C. District Court, in Nader v. Bork, stated that it was important to address the legality of Cox's dismissal to "give guidance for future conduct with regard to the Watergate inquiry." 65 The court held that firing Cox was illegal because he had not engaged in the extraordinary impropriety required by DOJ regulations. ${ }^{66}$ The decision was later vacated after U.S. v. Nixon was decided, but the case provided a platform for the court to admonish Nixon and his administration for dismissing Cox. ${ }^{67}$

The Watergate investigation changed the way the public and politicians viewed the nature and purpose of special prosecutor investigations. Previously, appointment of a special prosecutor was a tool the president used to ensure that the executive branch could objectively investigate its own officials. After Watergate, the special prosecutor served the pursuit of justice even if it meant pursuing the president. Nixon's brazen attempts to undermine the efforts of the special prosecutor convinced Congress to focus on special prosecutors' role. If they were to be the nation's instrument for fighting high-level corruption, lawmakers thought additional protection was needed to insulate the position from the president and other executive branch officials.

On October 26, 1978, almost five years to the date of Cox's dismissal, President Jimmy Carter signed into law the Ethics in Government Act, which, among other government ethics reforms, created procedures for conducting independent counsel investigations. ${ }^{68}$ In addition to creating the new "independent counsel" title, the law provided more robust protections against removal. The law also set out circumstances that would require the attorney general to appoint an independent counsel and required a more intensive confirmation process. ${ }^{69}$ In the aftermath of Watergate, Congress sought to create an office that could withstand the type of underhanded methods observed during the Nixon administration, and, in doing so, established a position with near-limitless discretion and limited checks on its authority. But the debate over the office of independent counsel was far from over.

\section{Post-Watergate Investigations Under the Ethics in Government Act}

Approximately 20 independent counsels were appointed under the Ethics in Government Act of 1978 before it expired in $1999 .{ }^{70}$ During this time, a few investigations stand out. The first,

\footnotetext{
${ }^{64}$ See Nader v. Bork, 366 F. Supp. 104 (D.D.C. 1973)

65 Id. at 106.

${ }^{66}$ Id. at 108.

${ }^{67}$ Nader v. Levi, 1975 U.S. Dist. LEXIS 16791 (D.D.C. 1975).

${ }^{68}$ Ken Gormley, An Original Model of the Independent Counsel Statute, 97 MiCH. L. REV. 601, 604, 608-09 (1998).

${ }^{69}$ See Adrianne C. Blake, You're Fired! Special Counsel Removal Authority and the Separation of Powers, 48 U. BALT.

L. Rev. 93, 100 (2018).

${ }^{70}$ Smaltz, supra note 26, at 2323.
}

\section{Democracy Clinic}


beginning during President Ronald Reagan's second term in 1986, was an investigation of highranking executive branch officials as part of what is commonly known as the Iran-Contra affair. ${ }^{71}$ Lawrence E. Walsh ${ }^{72}$ was appointed independent counsel to investigate a sale of arms to Iran in violation of an embargo and the subsequent diversion of the proceeds to support the right-wing rebel groups in Nicaragua known as the Contras. ${ }^{73}$ The investigation resulted in criminal charges against 14 individuals and several convictions, including of former Assistant to the President for National Security Affairs John Poindexter and former National Security Council staffer Oliver North. ${ }^{74}$ But these convictions were ultimately overturned, as Walsh's investigation and subsequent prosecutions were met with fierce opposition.

Critics chided Walsh for a variety of alleged missteps, such as the exorbitant cost of the investigation and prosecutions. ${ }^{75}$ Over six years, the government spent $\$ 35$ million, prompting public backlash. ${ }^{76}$ The legacy of the Iran-Contra affair "will likely be lost in the tumultuousness of the time and extravagance of this amount." ${ }^{77}$ However, not all were opposed to Walsh's investigation. In 1993, Attorney General Janet Reno testified regarding the reauthorization of the independent counsel statute, stating, "The Iran-Contra investigation, far from providing support for doing away with the Act, proves its necessity ... [T] [ is investigation could not have been conducted under the supervision of the Attorney General and concluded with any public confidence in its thoroughness or impartiality." 78

The 1994 investigation of then-Secretary of Agriculture Michael Espy garnered similar criticism. Independent Counsel Donald Smaltz investigated allegations that Espy accepted improper gifts, including sports tickets, lodging, and airfare. ${ }^{79}$ The investigation lasted four years and cost over $\$ 20$ million. ${ }^{80}$ Smaltz's office charged 13 individuals and six businesses with crimes, and 14 were convicted or pleaded guilty. Espy was indicted, but was acquitted on all 39 counts at trial. ${ }^{81}$

\footnotetext{
${ }^{71}$ Id. at 2339.

72 Walsh, Lawrence Edward, FED. JUD. CENTER, https://www.fjc.gov/history/judges/walsh-lawrence-edward.

73 The Iran-Contra Affair 20 Years On, NAT'L SEC. ARCHIVE (Nov. 24, 2006), https://nsarchive2.gwu.edu/NSAEBB/NSAEBB210.

${ }^{74}$ UNDERSTANDING THE IRAN-CONTRA AFFAIR, https://www.brown.edu/Research/Understanding_the_Iran_Contra_Affair/overview.pdf. See LAWRENCE E. WALSH, U.S. DeP't of Justice, Final Report of the Independent Counsel for IRAN/Contra Matters 562 (1993).

${ }^{75}$ Smaltz, supra note 26 , at 2358.

${ }^{76}$ Lawrence E. Walsh, The Need for Renewal of the Independent Counsel Act, 86 GEO L.J. 2379, 2384 n.12 (1998).

77 Smaltz, supra note 26, at 2358-59.

78 The Independent Counsel Reauthorization Act of 1993: Hearing on S. 24 Before the S. Comm. on Governmental Affairs, 103d Cong. 11 (1993) (statement of Janet Reno, Att'y Gen. of the United States).

79 Donald C. Smaltz, U.S. Dep't of Justice, Final Report of the Independent Counsel In Re: Alphonso Michael (Mike) Espy (2001), https://www.govinfo.gov/content/pkg/GPO-ICREPORT-ESPY/html/GPO-ICREPORT-ESPY-1.html.

${ }^{80} / d$.

81 ld.
}

\section{Democracy Clinic}


The next notable investigation began in 1994, when Kenneth Star was appointed independent counsel to investigate financial transactions involving President William Clinton and First Lady Hillary Clinton. Specifically, Starr probed the relationship between the Clintons and a series of purportedly fraudulent loans and real estate investments surrounding the Whitewater Development Corporation and other entities. ${ }^{82}$ The investigation led to several criminal charges, but none against the president or first lady. ${ }^{83}$ Although the Whitewater allegations served as the impetus for the investigation, they would ultimately have little to do with its legacy.

Starr's eventual report led to Clinton's impeachment. ${ }^{84}$ The investigation into the failed Arkansas land deal had already concluded when the judges overseeing Starr's investigation assigned his office to investigate allegations that Clinton perjured himself during a deposition in Clinton v. Jones, a sexual harassment lawsuit against Clinton. ${ }^{85}$ The ensuing investigation confirmed that Clinton had engaged a sexual relationship with Monica Lewinski, a White House intern. Drawing on Starr's report to Congress, the House of Representatives impeached Clinton for perjury and obstruction of justice based on Clinton's statements under oath about the relationship and his other alleged actions to cover it up. The Senate acquitted Clinton on both articles of impeachment. ${ }^{86}$

Starr has subsequently commented that there should have been another independent counsel to take on the Lewinsky investigation, but the only practical option was for his office to handle it given the lack of time and political appetite for another independent counsel. ${ }^{87}$ Even though Starr had recommended that his team take on the additional inquiry, he now asserts that "the most fundamental thing that could have been done differently" would have been for the Lewinsky matter to be investigated by others. ${ }^{88}$

Although many found Clinton's actions reproachable, others were equally outraged that the investigation strayed far beyond its initial focus to a public airing of Clinton's sexual misconduct.

\footnotetext{
82 Robert Williams, Political Scandals in the USA 64-66 (1998); Robert W. Gordon, Imprudence and Partisanship: Starr's OIC and the Clinton-Lewinsky Affair, 68 FORDHAM L. REV. 639, 641 (1999).

${ }^{83}$ Robert Ray, U.S. Dep't of Justice, Final Report of the Independent Counsel In Re: Madison Guaranty SAvings \& LoAn AsSOCIATION 155 app. 5 (2001), https://www.gpo.gov/fdsys/pkg/GPO-ICREPORT-MADISON/content-detail.html.

${ }^{84}$ Cynthia Brown \& Jared P. Cole, Cong. Research Serv., R44857, Special Counsel Investigations: History, Authority, APPOINTMENT AND REMOVAL 25 (2019).

85520 U.S. 681 (1997); Jones v. Clinton, 990 F. Supp. 657 (E.D. Ark. 1998).

${ }^{86}$ See David A. Graham \& Cullen Murphy, The Clinton Impeachment, as Told by the People Who Lived It, ATLANTIC (Dec. 2018), https://www.theatlantic.com/magazine/archive/2018/12/clinton-impeachment/573940/.

${ }^{87}$ Firing Line: Ken Starr (PBS television broadcast Mar. 20, 2020), https://www.pbs.org/video/ken-starr-qu5cvx/.

${ }^{88}$ Starr Regrets Lead Role in Clinton Investigation, DESERET NEWS (Dec. 4, 2004, 12:00 AM),

https://www.deseret.com/2004/12/4/19864833/starr-regrets-lead-role-in-clinton-investigation.
}

\section{Democracy Clinic}


Indeed, Starr's investigation received extensive criticism for its expansive jurisdiction, and many alleged that it lacked appropriate restraint. ${ }^{89}$

Each investigation under the Ethics and Government Act elicited criticism and sparked fierce debate over the Act's continued existence. The investigations faced criticisms from members of Congress and the public for exceeding their authority, either through unjustified expenditures of resources or overly expansive inquiries. It appeared to many that an independent counsel could keep investigating and spending without limit until some sort of wrongdoing was uncovered. Following the Iran-Contra and Whitewater investigations, debate intensified over the scope, cost, and value of these investigations. Ultimately, Congress allowed the independent counsel provision of the Ethics in Government Act to expire in 1999 with bipartisan support, marking the end of statutory law governing special counsel investigations to this day. ${ }^{90}$

\section{The Modern Special Counsel Office}

To fill the void left by the expiration of the independent counsel law, the DOJ promulgated new regulations in $1999 .{ }^{91}$ The rules gave the attorney general authority to appoint special counsels without seeking confirmation from a panel of judges, which the Ethics in Government Act had required. ${ }^{92}$ Although the appointee would no longer be referred to as an independent counsel, a special counsel would serve the same role: to conduct investigations that pose conflicts of interest for the DOJ. ${ }^{93}$ Taking into consideration the concerns that led to the expiration of the Ethics in Government Act, special counsels have less autonomy than independent counsels. Specifically, the attorney general (or deputy attorney general in the event of a recusal) oversees the investigations and has the authority to appoint and remove special counsels. ${ }^{94}$ Because these regulations were not promulgated pursuant to the notice-and-comment process outlined in the Administrative Procedure Act, ${ }^{95}$ the DOJ can unilaterally rescind them at any time, ${ }^{96}$ and the rescission would not be subject to judicial review.

\footnotetext{
${ }^{89}$ See Susan Schmidt \& Dan Morgan, Hearings to Reveal Man Behind Curtain, WASH. Post (Nov. 19, 1998), https://www.washingtonpost.com/wp-srv/politics/special/clinton/stories/starr111998.htm. See also Lanny J. Davis, Did Starr Set a Perjury Trap? A Series of Questionable Events Brings Attention to What Starr Knew and When He Knew It in the Clinton Investigation, BALT. Sun (Nov. 1, 1998), https://www.baltimoresun.com/news/bs-xpm1998-11-01-1998305008-story.html.

${ }^{90}$ BROWN \& COLE, supra note 84.

${ }^{91}$ See 28 C.F.R. $\S 600$ (1999).

9228 C.F.R. § 600.1 (1999); BROWN \& COLE, supra note 84, 4-6.

93 James K. Robinson, After the Independent Counsel Act: Where Do We Go from Here?, 51 HASTINGS L.J. 733,735 (2000).

9428 C.F.R. $\S 600.7$ (1999).

95 See 5 U.S.C. $§ 553$ (2018).

96 Josh Blackmun, Can the Special Counsel Regulations Be Unilaterally Revoked?, LAWFARE (July 5, 2018, 7:22 AM), https://www.lawfareblog.com/can-special-counsel-regulations-be-unilaterally-revoked.
}

\section{Democracy Clinic}


The most recent special counsel investigation occurred in the wake of the 2016 election of President Donald Trump. Throughout the campaign, the Trump campaign's connections to Russia and its election interference efforts were a frequent subject of speculation. ${ }^{97}$ In the early months of the Trump administration, FBI Director James Comey revealed that the FBI had opened an investigation before the election into the campaign's ties to Russia. ${ }^{98}$ During the investigation, Trump purportedly pressured Comey to cease the investigation of Michael Flynn, the national security advisor and one of Trump's most visible supporters during the campaign. ${ }^{99}$ Attorney General Jeff Sessions recused himself from overseeing the investigations into Russian campaign interference due to his work for the Trump campaign. Supervision of the investigations fell to Deputy Attorney General Rod Rosenstein. ${ }^{100}$ Trump fired Comey on May 9, 2017, ${ }^{101}$ and, as public outcry reached a crescendo in the following week, Rosenstein appointed Robert Mueller to serve as special counsel. ${ }^{102}$ Mueller's mandate included the authority to investigate "any links and/or coordination" between the Russian government and the Trump campaign as well as "matters that arose or may arise directly from the investigation." 103

Rosenstein's selection of Mueller was met with widespread approval. ${ }^{104} \mathrm{~A}$ former FBI director, Mueller was highly respected by Republicans and Democrats alike. Initially appointed FBI director by President George W. Bush, President Barack Obama had taken the unusual step of extending Mueller's ten-year term by two years with congressional approval. ${ }^{105}$

\footnotetext{
97 Trump fed into this controversy when he appeared to publicly ask Russia to hack opponent Hillary Clinton's email server, although he later claimed that he was "joking." Marshall Cohen, Trump Says He Joked About Wanting Russian Help in 2016. The Facts Tell a Different Story., CNN (Mar. 5, 2019, 6:27 AM), https://www.cnn.com/2019/03/05/politics/trump-emails-joke/index.html.

${ }^{98}$ Russell Berman, It's Official: The FBI Is Investigating Trump's Links to Russia, ATLANTIC (Mar. 20, 2017, 5:46 PM), https://www.theatlantic.com/politics/archive/2017/03/its-official-the-fbi-is-investigating-trumps-links-torussia/520134/.

${ }_{99}^{9}$ Michael S. Schmidt, Comey Memo Says Trump Asked Him to End Flynn Investigation, N.Y. TIMES (May 16, 2017), https://www.nytimes.com/2017/05/16/us/politics/james-comey-trump-flynn-russia-investigation.html.

100 Steven Harper, A Timeline: Everything We Know About the Comey Firing, BILL Moyers (Apr. 24, 2018), https://billmoyers.com/story/comey-timeline/.

${ }^{101}$ Trump Fires Comey Amid Russian Election Probe, 83 TeleCOMM. ReP. 24, 24-25 (2017).

102 Rod J. Rosenstein, Off. Of the Deputy Att'y Gen., 3915-2017, Appointment of SPeCial Counsel to InVESTIGATE Russian Interference With the 2016 Presidential Election and Related Matters (May 17, 2017), https://www.justice.gov/opa/press-release/file/967231/download.

103 Id.

${ }^{104}$ Russell Berman, Mueller Pick Meets a Rare Bipartisan Consensus, ATLANTIC (May 18, 2017, 10:00 AM), https://www.theatlantic.com/politics/archive/2017/05/mueller-pick-achieves-a-rare-bipartisanconsensus/527133/.

105 Obama Requests 2 More Years for FBI Chief, CNN (May 13, 2011, 12:04 PM), https://www.cnn.com/2011/POLITICS/05/12/obama.mueller/index.html.
}

\section{Democracy Clinic}


After the Special Counsel's Office assumed control of the investigation, Mueller assembled a group of renowned prosecutors. ${ }^{106}$ Trump and his allies frequently attacked the investigation, often referring to it as a "witch hunt."107 At one point, Trump allegedly demanded Mueller's firing, only to back down when White House Counsel Donald McGahn threatened to resign rather than ask the DOJ to carry out the directive. ${ }^{108}$

Over the course of approximately two years, the Mueller team indicted 34 individuals. ${ }^{109}$ They secured convictions against several members of Trump's inner circle, including campaign manager Paul Manafort and longtime confidant and political strategist Roger Stone. ${ }^{110}$ As the inquiry expanded, Deputy Attorney General Rosenstein stated that he would recuse himself from overseeing it if his role in Comey's firing became a point of contention, ${ }^{111}$ but he never did. Mueller's investigation primarily sought to address two issues: (1) whether members of the Trump campaign conspired with Russian operatives to aid in Trump's election victory and (2) whether Trump illegally obstructed the investigation.

In March 2019, the Special Counsel's Office concluded its investigation and summarized its findings in a voluminous report. The report concluded that Russia had made a concerted effort to aid the Trump campaign through a social media misinformation campaign as well as "hacking-and-dumping" operations, which involved the release of emails stolen from members of Hillary Clinton's presidential campaign and the Democratic National Committee. ${ }^{112}$ Nevertheless, Mueller and his team concluded that there was not sufficient evidence to support conspiracy charges against Trump campaign officials, ${ }^{113}$ although several were convicted at trial or pled guilty to lying to investigators. ${ }^{114}$ Mueller declined to make a prosecutorial decision on

\footnotetext{
106 The group included terrorism expert Zainab Ahmad, veteran Supreme Court advocate Michael Dreeban, and the chief of the DOJ's criminal fraud division, Andrew Weissman, among others. Dareh Gregorian, Meet Mueller's Team: The Best Prosecutors in the Business or 'Angry Democrats'?, NBC News (Mar. 23, 2019, 10:37 AM), https://www.nbcnews.com/politics/donald-trump/meet-mueller-s-team-best-prosecutors-business-or-angrydemocrats-n976226.

107 See, e.g., Donald J. Trump (@realDonaldTrump), TWITTER (July 13, 2019, 12:22 AM), https://twitter.com/realDonaldTrump/status/1149896948507430912.

108 Michael S. Schmidt \& Maggie Haberman, Trump Ordered Mueller Fired, but Backed Off When White House Counsel Threatened to Quit, N.Y. TIMES (Jan. 25, 2018), https://www.nytimes.com/2018/01/25/us/politics/trumpmueller-special-counsel-russia.html.

${ }^{109}$ Ryan Teague Beckwith, Here Are All of the Indictments, Guilty Pleas and Convictions from Robert Mueller's Investigation, TIME (Nov. 15, 2019, 2:32 PM), https://time.com/5556331/mueller-investigation-indictments-guiltypleas/.

${ }^{110} / d$.

${ }^{111}$ Sadie Gurman et al., Special Counsel Mueller's Investigation Seems to Be Growing, AssociatEd PrESS (June 3, 2017), https://apnews.com/2fa69c1f399c485e96cc312f7a5039ec.

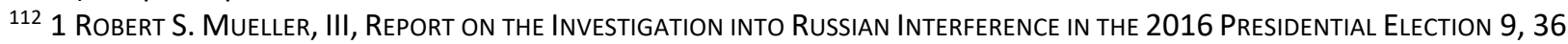
(2019).

113 Id. at 9.

${ }^{114}$ Id.
}

\section{Democracy Clinic}


whether Trump committed obstruction of justice, ${ }^{115}$ but also refused to exonerate him. ${ }^{116}$ This decision was grounded in the Office of Legal Counsel's opinion that it would be unconstitutional to indict a sitting president. ${ }^{117}$

In accordance with DOJ rules, the Special Counsel's Office submitted its report to Attorney General William Barr. ${ }^{118}$ Two days later, Barr sent a four-page letter to Congress, in which he claimed to summarize the report's contents. ${ }^{119}$ However, three days later, Mueller wrote a letter to Barr asserting that the letter to Congress did not accurately reflect the report's contents. ${ }^{120}$ Eventually, the DOJ released a redacted copy of the Mueller report to the public. ${ }^{121}$ Allegations that Barr misled the public regarding the contents of the report and that redacted materials were inappropriately withheld continue to this day. ${ }^{122}$

As with prior special prosecutor investigations, the events of the Mueller investigation spurred talk of reforming the system. ${ }^{123}$ Some commentators have criticized Mueller for his refusal to make a decision regarding Trump's conduct and for the manner in which his findings were conveyed to the public. ${ }^{124}$ Even one of the most senior prosecutors in Mueller's office, Andrew Weissmann, voiced criticisms. In a book he wrote about the investigation, Weissmann said Mueller's team should have been more aggressive, such as by subpoenaing Trump for an interview and probing Trump's financial records. He claimed that the decisions to shy away from more assertive tactics were influenced by concerns that Trump would fire Mueller. ${ }^{125}$

1152 Robert S. MUeller, III, RePORT ON the INVESTIGATION INTO RUSSIAN INTERFERENCE IN THE 2016 PRESIDENTIAL ELECTION 1-2 (2019).

116 Id. at 8.

117 A Sitting President's Amenability to Indictment and Criminal Prosecution, 24 Op. O.l.C. 222, 222,260 (2000).

118 See 28 C.F.R. $\S 600.8$ (c) (1999).

${ }^{119}$ See Letter from William P. Barr, Att'y Gen. of the United States, to Lindsey Graham, Chairman of the Senate Comm. on the Judiciary et al. (Mar. 24, 2019), https://games-

cdn.washingtonpost.com/notes/prod/default/documents/9048a12b-2332-4645-a1bed645db216eb5/note/6f3248a4-4d94-4d5f-ad42-8ff6ccb1a89e.pdf\#page=1.

${ }^{120}$ Devlin Barrett \& Matt Zapotsky, Mueller Complained That Barr's Letter Did Not Capture 'Context' of Trump Probe, WASH. POST (Apr. 30, 2019, 8:21 PM), https://www.washingtonpost.com/world/national-security/muellercomplained-that-barrs-letter-did-not-capture-context-of-trump-probe/2019/04/30/d3c8fdb6-6b7b-11e9-a66da82d3f3d96d5_story.html.

${ }^{121}$ Sarah Mervosh, 'Redacted' Is the Word of the Day as the Mueller Report Lands, N.Y. TIMES (Apr. 18, 2019), https://www.nytimes.com/2019/04/18/us/politics/redacted-mueller-report.html.

122 See Memorandum Opinion at 22, Elec. Privacy Info. Ctr. v. United States Dep't of Justice, No. 1:19-cv-00810 (D.D.C. Mar. 5, 2020).

${ }^{123}$ Senators Thom Tillis and Chris Coons introduced bipartisan legislation to offer the special counsel greater removal protections while the inquiry was under attack from the Trump administration. See Special Counsel Integrity Act, S. 1741, 115th Cong. (2017). The bill never made it out of the Senate Judiciary Committee. ${ }^{124}$ Video Interview with William M. Treanor, Dean, Georgetown University Law Center (Mar. 27, 2020); Video Interview with Mark H. Tuohey, Of Counsel, Baker \& Hostetler LLP (Apr. 1, 2020).

${ }^{125}$ Charlie Savage, Mueller's Team Should Have Done More to Investigation Trump-Russia Links, Top Aide Says, N.Y. TIMES (Sept. 21, 2020), https://www.nytimes.com/2020/09/21/us/politics/andrew-weissmann-mueller.html; see also George Packer, The Inside Story of the Mueller Probe's Mistakes, ATLANTIC (Sept. 21, 2020),

\section{Democracy Clinic}


Mueller rejected Weissmann's critiques, dismissing them as based on “incomplete information." 126

The Mueller report has not established a consensus regarding the Trump campaign's connections to Russia and the president's role in a possible cover-up. Some use the report as proof of misconduct, while Trump claims "Total EXONERATION."127

\section{Reform Recommendations}

To provide for independent investigations that ameliorate actual or perceived conflicts of interest in the DOJ, we recommend restoring a statutory scheme for regulating special counsel investigations. Under our proposal, the power to appoint and oversee special counsels would be balanced between the attorney general and a special division of the federal judiciary consisting of a three-judge panel. This approach would divide the responsibilities pertaining to preliminary investigations, appointment, the scope of authority, oversight, removal, termination, and release of findings. Congress would have additional checks and oversight power. This Part explains each aspect of the proposal, including by drawing on comparisons to the past and current approaches to special counsel investigations. Our recommendations are divided into seven elements and are summarized as follows:

1. Pre-Appointment: While the attorney general retains authority and discretion to conduct a preliminary investigation to determine whether a special counsel is needed, our proposed statute provides for more formal recusal standards and checks on inaction by the attorney general.

2. Appointment: The attorney general nominates and the Special Division of the judiciary confirms special counsels.

3. Scope of Authority: The Special Division sets the initial scope of an investigation and reviews any proposed changes to that scope.

https://www.theatlantic.com/politics/archive/2020/09/andrew-weissmann-mueller-book-where-lawends/616395/.

${ }^{126}$ Michael S. Schmidt, Mueller Rebuts Insider's Claim That He Could Have Done More to Investigate Trump, N.Y. TIMES (Sept. 29, 2020), https://www.nytimes.com/2020/09/29/us/politics/robert-mueller-andrewweissmann.html.

127 Donald J. Trump (@realDonaldTrump), TWITTER (Mar. 24, 2019, 4:42 PM), https://twitter.com/realDonaldTrump/status/1109918388133023744; see Sarah N. Lynch, Mueller Report Shows Evidence Trump Committed Crimes, House Judiciary Chairman Says, ReUTERS (July 21, 2019, 11:00 AM), https://www.reuters.com/article/us-usa-trump-nadler/mueller-report-shows-evidence-trump-committed-crimeshouse-judiciary-chairman-says-idUSKCN1UGOIK.

\section{Democracy Clinic}


4. Oversight: The attorney general maintains primary oversight of the investigation, but the attorney general is required to submit reports to Congress whenever he or she prevents the special counsel from taking an action.

5. Removal: The attorney general is authorized to remove a special counsel with approval from the Special Division.

6. Termination: Investigations will have no formal timelines; termination of investigations can be triggered either by the special counsel or the attorney general with the Special Division's consent.

7. Release of Findings: The special counsel must submit a report at the conclusion of his or her investigation to the chairs and ranking members of the Senate and House Judiciary Committees. The report must include a clear statement as to whether the special counsel believes the subjects of the investigation committed crimes, including evidence gathered and investigative methods used to reach that determination.

\section{A. Pre-Appointment}

Prior to the appointment of a special counsel, the DOJ has historically conducted a preliminary investigation to determine whether a special counsel is necessary. These preliminary investigations have typically been spurred by pressure from Congress and the public.

\section{Ethics in Government Act}

Under the Ethics in Government Act, the first stage of a potential independent counsel inquiry consisted of a preliminary investigation conducted by the attorney general. The Act required the DOJ to conduct such an investigation upon receiving information suggesting that high-level executive branch officials may have broken the law. ${ }^{128}$ The details of the investigation remained confidential, but the attorney general was obligated to inform the judges on the Special Division of its existence. ${ }^{129}$ If, after 30 days, the attorney general determined that the information was credible, the preliminary investigation would be extended for up to 90 days. Based on the conclusions of that investigation and the credibility of the allegation, the attorney general was authorized to request that the special division appoint an independent counsel. Using information provided by the attorney general, the court would select an independent counsel to oversee the investigation. ${ }^{130}$

\footnotetext{
${ }^{128}$ BROWN \& COLE, supra note 84 , at 5.

129 ld. at 7.

13028 U.S.C. $§ 592$ (1994).
}

\section{Democracy Clinic}




\section{Current Department of Justice Regulations}

Under the DOJ's current regulations, a special counsel is appointed by the attorney general, at his or her discretion, pursuant to his or her general administrative hiring authority. ${ }^{131}$ Like the prior regime, appointment virtually always takes place after the DOJ conducts a preliminary investigation. ${ }^{132}$ The regulations specify that, in the event of an attorney general's recusal from the matter for a conflict of interest, the deputy attorney general handles appointment and oversight. $^{133}$

Attorney General Sessions' recusal from initiating and overseeing the Mueller investigation was virtually inescapable under DOJ guidelines, ${ }^{134}$ given his involvement with the Trump campaign and his meetings with the Russian ambassador during the campaign, which he failed to disclose during his Senate confirmation hearings. ${ }^{135}$ But the recusal did not come until a watchdog organization filed a complaint with the DOJ's Office of Professional Responsibility, and Sessions' subsequent consultation with that office, that he recused himself from the investigation. ${ }^{136}$ Sessions also faced a "Republican chorus of calls for recusal that forced the issue."137

13128 C.F.R. $\S 600.1$ (1999). See BROWN \& COLE, supra note 84, at 8.

132 See 28 C.F.R. $§ 600$ (1999).

133 Id.

134 See 28 C.F.R. $§ 45.2$ (1999) (stating that "no employee shall participate in a criminal investigation or prosecution if he has a personal or political relationship with: (1) Any person or organization substantially involved in the conduct that is the subject of the investigation or prosecution; or (2) any person or organization which he knows has a specific and substantial interest that would be directly affected by the outcome of the investigation or prosecution.").

135 Karoun Demirjian et al., Attorney General Jeff Sessions Will Recuse Himself From Any Probe Related to 2016 Presidential Campaign, WASH. POST (Mar. 2, 2017), https://www.washingtonpost.com/powerpost/top-goplawmaker-calls-on-sessions-to-recuse-himself-from-russia-investigation/2017/03/02/148c07ac-ff46-11e6-8ebe6e0dbe4f2bca_story.html; Adam Entous et al., Sessions Met with Russian Envoys Twice Last Year, Encounters He Later Did Not Disclose, WASH. POST (Mar. 1, 2017), https://www.washingtonpost.com/world/nationalsecurity/sessions-spoke-twice-with-russian-ambassador-during-trumps-presidential-campaign-justice-officialssay/2017/03/01/77205eda-feac-11e6-99b4-9e613afeb09f_story.html.

${ }^{136}$ Fred Wertheimer \& Donald Simon, Sessions' Recusal and Rosenstein's Appointment of a Special Counsel-Both Were Legally Required, JUST SECURITY (Sept. 17, 2018), https://www.justsecurity.org/60757/sessions-recusalrosensteins-appointment-special-counsel-both-legally-required/.

137 Jeff Greenfield, Why Sessions Recused Himself, Politico (Mar. 2, 2017),

https://www.politico.com/magazine/story/2017/03/sessions-recuses-himself-trump-russia-214857.

\section{Democracy Clinic}




\section{Recommendation}

Under our proposal, the attorney general would still conduct a preliminary investigation. This phase of the investigation should remain in the DOJ's purview, given the executive branch's constitutional and historic responsibility for originating criminal investigations. But the lack of a remedy for inaction under the Ethics in Government Act and the current special counsel regulations is problematic. Accordingly, to further the goal of striking a balance between independence and accountability while respecting constitutional separation of powers, our proposed statute would increase accountability for attorneys general in their decisions to recuse themselves from special counsel investigations and to pursue appointments of special counsels.

The proposed statutory scheme would provide more precise standards for determining when an attorney general should recuse himself or herself from an investigation. It would formally require DOJ's Office of Professional Responsibility ("OPR"), ${ }^{138}$ or another internal DOJ ethics entity, to ensure a review is conducted of the attorney general's potential conflicts of interest. OPR would have an affirmative responsibility to continuously review whether an ethics or conflict of interest consultation should take place, especially when investigations involve certain high-level executive branch officials, such as the president, vice president, and Cabinet secretaries. Examples from the American Bar Association Model rules on conflicts of interest, including personal conflicts, financial conflicts, material limitations and more, could supplement the DOJ's existing guidelines. ${ }^{139}$ Following a consultation, OPR could submit a report that makes a recommendation as to whether the attorney general's recusal is necessary. The attorney general could decline to recuse himself or herself, but would be required to appear before the House or Senate Judiciary Committee to explain the decision.

We also recommend a mechanism for challenging an attorney general's refusal to appoint or consider appointing a special counsel. Our proposed statute would provide standards that trigger an obligation for the attorney general to appoint a special counsel or open a preliminary investigation to determine whether appointment of a special counsel is necessary. First, the statute would require appointment of a special counsel when certain high-level executive branch officials, such as the president, vice president, attorney general, and Cabinet secretaries, are suspected of personally having committed a federal crime and deemed a "subject" of an

\footnotetext{
138 See Office of Professional ResponsibiLity, U. S. DeP'T of Justice, https://www.justice.gov/opr (last visited July 14, 2020) ("OPR's primary mission is to ensure that Department attorneys perform their duties in accordance with the high professional standards expected of the nation's principal law enforcement agency ... OPR's primary responsibility is to investigate allegations that Department attorneys, prosecutors, and immigration judges have committed misconduct while performing their duties to investigate, litigate, or give legal advice.").

${ }_{139}$ Model Rules of Professional Conduct: Rule 1.7: Conflicts of Interest: Current Clients, A.B.A., https://www.americanbar.org/groups/professional_responsibility/publications/model_rules_of_professional_con duct/rule_1_7_conflict_of_interest_current_clients/ (last visited July 14, 2020).
}

\section{Democracy Clinic}


investigation. ${ }^{140}$ Second, the statute would allow the chairs and ranking members of the House and Senate Judiciary Committees to petition the attorney general to initiate an investigation or the appointment process. A mix of Democrats and Republicans always hold these positions, which would make the petition process viable regardless of which party controlled the White House. After a petition's submission, the attorney general would have 21 days to appoint a special counsel or submit an explanation of the decision not to. Even though members of Congress could not mandate appointment of a special counsel through this process, it is apparent throughout history that public and political pressure is usually the catalyst behind special counsel appointments. ${ }^{141}$

\section{B. Appointment}

The power to appoint a special counsel has alternated between the attorney general and the judiciary over the last century. ${ }^{142}$ Prior to passage of the Ethics in Government Act, special prosecutors were not appointed pursuant to any particular statutory authority. Instead, the president or attorney general would appoint a special prosecutor at their discretion. ${ }^{143}$ Perhaps the most significant change to special counsel procedures under the Ethics in Government Act was the establishment of new mechanisms for appointment of those charged with leading independent investigations and prosecutions. ${ }^{144}$ Virtually all special counsel appointees since passage of the Ethics and Government Act have been highly regarded and respected. ${ }^{145}$ In fact, attorneys general have historically selected aggressive special counsels, decisions, which, in many cases, may have been motivated by political considerations, such as warding off criticism and ensuring that findings that benefit officials are viewed as credible by the public. ${ }^{146}$

\section{Ethics in Government Act}

The Ethics in Government Act provided for appointment of a special prosecutor to investigate and prosecute high-ranking executive branch officials under certain circumstances. The statute provided for appointment of "independent counsels" by a three-judge panel, called a "Special Division" of the judiciary, upon the attorney general's request. ${ }^{147}$ The conclusions resulting

${ }^{140}$ According to the DOJ Handbook, a "subject" is "a person whose conduct is within the scope of a Grand Jury's investigation." See U. S. Dep'T OF JUSTICE, JUSTICE MANUAL (2018), https://www.justice.gov/jm/jm-9-11000-grandjury\#9-11.152.

${ }^{141}$ See, e.g., Rebecca R. Ruiz \& Mark Landler, Robert Mueller, Former F.B.I. Director, Is Named Special Counsel for Russia Investigation, N.Y. TIMEs (Mar. 17, 2017), https://www.nytimes.com/2017/05/17/us/politics/robert-muellerspecial-counsel-russia-investigation.html; Blake, supra note 69, at 98-99.

${ }^{142}$ See generally supra Part I.

${ }^{143}$ See supra Part I.A.

${ }^{144}$ See 28 U.S.C. §§ 592(c), 593(b) (1994).

${ }^{145}$ Video Interview with Mark H. Tuohey, supra note 124.

${ }^{146}$ Video Interview with William M. Treanor, supra note 124.

${ }^{147} 28$ U.S.C. $\S \S 49,593(b)$ (1994).

\section{Democracy Clinic}


from the preliminary investigation determined whether an independent counsel would be appointed, leaving significant discretion to the attorney general. The statute directed the attorney general to request an independent counsel appointment where he or she either: (1) deemed that further investigation was warranted following the preliminary investigation or (2) failed to determine that investigation was not warranted after the passing of the 90-day window for the preliminary investigation. ${ }^{148}$ If the attorney general requested appointment, he or she was required to provide the Special Division with sufficient information to assist in selecting the independent counsel and defining the investigation's scope and jurisdiction. ${ }^{149}$ The Special Division then had final authority to select the independent counsel. ${ }^{150}$

In 1988, the Supreme Court in Morrison v. Olson held that the judiciary's role in the appointment of an independent counsel was constitutional. ${ }^{151}$ The Court deemed the independent counsel's role to be one of an "inferior" officer, who reports to a "principal" officer (the attorney general). ${ }^{152}$ Independent counsels' status as inferior officers, in the Court's analysis, prevented their appointment by the judiciary from violating separation-of-powers principles and the constitutional requirement that the president nominate principal officers. ${ }^{153}$ Indeed, other special courts with limited powers have been established from time to time. ${ }^{154}$

Even after Morrison, there has been significant debate over the constitutionality of legislation allowing courts to appoint special counsels. Opponents maintain that judicial appointment is barred by the Appointments Clause's requirement that the president nominate certain executive branch officials with the advice and consent of the Senate. ${ }^{155}$ And although Congress may establish executive branch agencies and conduct oversight of those entities, it is prohibited from engaging in criminal prosecutions, which fall within the purview of the executive powers granted to the president in Article II. ${ }^{156}$ Accordingly, legislation granting the judiciary the power to appoint special counsels may raise concerns of impermissible congressional aggrandizement. But proponents of the Ethics in Government Act cite Morrison's reasoning and argue that

14828 U.S.C. § 592 (1994).

149 /d.

150 BROWN \& COLE, supra note 84, at 6.

${ }^{151}$ Morrison v. Olson, 487 U.S. 654 (1988).

152 Id. See also U.S. ConST. art. II, § 2, cl. 2.

153 U.S. CONST. art. II, § 2, cl. 2.

154 For example, the Foreign Intelligence Surveillance Court is a federal court authorized to oversee requests for surveillance warrants against foreign agents by federal law enforcement and intelligence authorities, pursuant to the Foreign Intelligence Surveillance Act ("FISA"). The FISA Court's judges are appointed by the chief justice of the United States without confirmation or oversight by Congress. See The Foreign Intelligence Surveillance Court, WASH. POST (June 7, 2013), https://www.washingtonpost.com/politics/the-foreign-intelligence-surveillancecourt/2013/06/07/4700b382-cfec-11e2-8845-d970ccb04497_graphic.html.

155 Id.; see Andrew B. Pardue, 'When the President Does It': Why Congress Should Take the Lead in Investigations of Executive Wrongdoing, 61 WM. \& MARY L. REV. 573, 590 (2019).

${ }^{156}$ See U.S. CONST. art. II, $§ 1$, cl. 1.

\section{Democracy Clinic}


legislation calling for judicial appointment provides a meaningful device for checks and balances by insulating investigations of executive officials from improper interference from the executive branch. ${ }^{157}$

\section{Current Department of Justice Regulations}

The current DOJ regulations do not involve the federal judiciary; the power to appoint special counsels remains with the attorney general. The goal of this aspect of the regulations was to shift the balance between independence and accountability more toward accountability in light of the concerns about the wide scopes of the Iran-Contra and Whitewater investigations. ${ }^{158}$ Under current regulations, appointment is warranted only in the most "extraordinary circumstances," where normal DOJ investigative processes would result in a conflict of interest or the public interest would be best served by removing responsibility from the DOJ. ${ }^{159}$

The attorney general has almost complete discretion in determining whether and when appointment is appropriate, but there are some guidelines as to who can be appointed. A special counsel must come from outside of the government and must be a lawyer with a reputation for integrity and impartial decision making, along with appropriate experience. ${ }^{160}$ The attorney general may appoint a special counsel immediately, conduct a preliminary investigation first, or simply attempt to mitigate any conflicts of interest within the DOJ, including through recusal of particular individuals. ${ }^{161}$

Proponents of the existing regulations might argue that an increased role for the attorney general in appointment is needed to prevent out of control investigations. Conversely, opponents might argue that in an age of growing politicization of the attorney general position, the regulations give a partisan attorney general power to prevent credible investigations into political allies. Indeed, as Professor Jed Shugerman asserts, "the twentieth century ushered in more partisan insiders, hacks, and fixers, just as the DOJ's power grew enormously." 162 With no statutory right of action or means of judicial review, the power to appoint individuals charged with investigating the executive branch rests solely within the executive branch.

\section{Recommendation}

Our proposed statute provides an appointment scheme where the attorney general would nominate a special counsel to be confirmed by a Special Division of judiciary comprised of a

\footnotetext{
157 See Pardue, supra note 155 , at 588-89.

158 Supra Part I.C.

15928 C.F.R. § 600.1 (1999).

16028 C.F.R. $\S 600.3$ (1999).

16128 C.F.R. $§ 600.2$ (1999).

162 See Jed Handelsman Shugerman, Professionals, Politicos, and Crony Attorneys General: A Historical Sketch of the U.S. Attorney General as a Case for Structural Independence, 87 FoRdHAM L. REV. 1965, 1966-67 (2019).
}

\section{Democracy Clinic}


three-judge panel appointed by the chief justice of the United States. ${ }^{163}$ Given the Supreme Court's holding in Morrison, the Special Division's role in the appointment process should not be vulnerable to legal challenges. Subjecting the attorney general's selection to the Special Division's approval provides a layer of security against appointment of an ill-suited special counsel, and promotes both independence and accountability of special counsels.

If the Special Division rejected a proposed appointee, the attorney general would be allowed to propose another candidate. Our recommendation envisions that the special division would give broad deference to the attorney general in approving the special counsel nominee, and would only reject a nominee upon a clear showing of good cause, such as where the nominee clearly lacked requisite experience or had a conflict of interest.

\section{Scope}

Defining and controlling the scope of a special counsel investigation presents significant challenges related to objectivity, efficiency, and the separation of powers. Kenneth Starr's broad scope during the Whitewater investigation was a significant consideration in Congress's decision to allow the Ethics in Government Act to expire in 1999. ${ }^{164}$ Although considerable deference to the independent counsel proved fatal to the Act, it was initially seen as a necessary precaution to prevent a biased attorney general from stunting an investigation. President Nixon's attempt to end the special prosecutor investigation into the Watergate scandal and Attorney General Mitchell's involvement in the scandal made robust discretion for the independent counsel seem essential. ${ }^{165}$ Reform must strike a balance between restraint of powers and freedom from interference.

\section{Ethics in Government Act}

Under the Ethics in Government Act, the formal scope of an independent counsel's jurisdiction would be defined by the Special Division of the judiciary at the outset of the investigation. ${ }^{166}$ The independent counsel was vested with the power of the entire DOJ other than those powers reserved explicitly for the attorney general, ${ }^{167}$ and the Independent Counsel's Office was entitled to request any assistance or provisions from the DOJ necessary for the investigation,

\footnotetext{
163 Like the Ethics in Government Act and the Foreign Intelligence Surveillance Act, the Special Division judges would be selected by the chief justice of the United States without confirmation by Congress.

${ }^{164}$ Abraham Dash, The Office of Independent Counsel and the Fatal Flaw: "They Are Left to Twist in the Wind", 60 MD. L. Rev. 26, 34-36 (2001).

165 See supra Part I.B.

${ }^{166}$ BROWN \& COLE, supra note 84, at 6.

${ }^{167}$ Id. at 11-12.
}

\section{Democracy Clinic}


not subject to any budgetary limits. ${ }^{168}$ With these considerable powers at hand, independent counsels were able to undertake wide-ranging investigations. ${ }^{169}$

The primary purpose of the Ethics in Government Act's independent counsel rules was to insulate the independent counsel from executive control. Granting the judiciary power to define the scope of the investigation, rather than the attorney general, was a crucial step to achieving that insulation. A biased attorney general with the power to define scope would be able to tailor the scope of an investigation to affect its outcome. Placing this responsibility with the judiciary provided an objective check against politicization and supported the perception that the investigations were unbiased. The principal objection to this provision was that it violated the separation of powers doctrine. ${ }^{170}$ Many saw the power to define the scope of an investigation as a purely executive function and believed the judiciary's involvement was an improper encroachment on the executive branch's powers. But the Supreme Court rejected a challenge to the law on this basis in Morrison. ${ }^{171}$

\section{Current Department of Justice Regulations}

The current DOJ regulations let the attorney general determine the special counsel's jurisdiction "with a specific factual statement of the matter to be investigated." 172 The regulations also give the special counsel authority to investigate any federal crimes committed related to the investigation, such as obstruction of justice. ${ }^{173} \mathrm{~A}$ special counsel must receive authorization from the attorney general to expand the scope of an investigation beyond its original mandate. ${ }^{174}$ Independent counsels under the Ethics in Government Act had the "independent authority to exercise all investigative and prosecutorial functions [] of the Department of Justice," 175 whereas special counsels are only vested with the "investigative and prosecutorial functions of any United States Attorney." ${ }^{176}$ Although this change has had little effect on the formal powers of the special counsel, it denotes a clear shift in the perception of the role. By likening the office to "any U.S. Attorney," the regulation sends a clear message that the special counsel is subordinate to the attorney general, like all other DOJ employees.

\footnotetext{
168 See Gormley, supra note 68, at 674.

${ }^{169}$ See BRown \& Cole, supra note 84, at 6-7.

170 Id. at 24.

${ }^{171}$ Morrison v. Olson, 487 U.S. 654, 685-96 (1988).

17228 C.F.R. $\S 600.4($ a) (1999).

173 Id.

17428 C.F.R. § 600.4(b) (1999).

17528 U.S.C. § 594 (1994).

17628 C.F.R. § 600.6 (1999).
}

\section{Democracy Clinic}




\section{Recommendation}

To protect the scope of investigations from improper influence, we recommend placing the authority to define scope with the three-judge panel of the Special Division. At the same time that the panel approved the attorney general's proposed appointee, it would provide the special counsel with the initial scope of the investigation. Once the investigation was underway, any changes to the formal scope of the investigation would require approval from the Special Division.

Deferring to the judiciary is essential to insulate investigations from political interference, but the judiciary's role should be balanced with input from the attorney general to ensure that the investigation proceeds efficiently. Accordingly, the attorney general would still have input over what matters fall within the scope of an investigation and what matters may be referred back to the DOJ. Allowing the attorney general to retain this power would enable investigations to function more smoothly, and it would respect the attorney general's autonomy. However, if the attorney general referred a matter discovered by the special counsel back to the DOJ, he or she would need to submit a report to the Special Division explaining the decision. The special counsel would also have the ability to refer investigative matters or prosecutions to the DOJ, as Mueller often did in his recent investigation, resulting in an additional 14 prosecutions. ${ }^{177}$ This system would allow the attorney general to exercise discretion over a core executive function, while providing for review of that discretion. If the Special Division determined that the attorney general made an improper decision, it could return the matter in question back to the Special Counsel's Office. Further, issuing reports to the judiciary creates a paper trail of the attorney general's decisions and reasoning, and would incentivize the attorney general to act appropriately, if only to avoid the appearance of impropriety.

In contrast to more overt efforts to undermine an investigation, such as firing the special counsel, limiting the scope of an investigation would be a more covert and potentially untraceable way to interfere with an investigation. Our recommended reform addresses this unique problem by compelling the attorney general to justify such decisions to an independent third party or, where necessary, by removing those decisions from his or her discretion entirely. However, the attorney general would maintain enough discretion, combined with oversight powers, to keep an overzealous special counsel properly restrained.

177 Zachary Basu, Mueller Referred 14 Criminal Cases for Outside Prosecution, Axıos (Apr. 18, 2019), https://www.axios.com/mueller-referred-14-cases-prosecution-c8455658-02ff-4f4a-bda8-a04ea7b7be21.html.

\section{Democracy Clinic}




\section{Oversight}

The Ethics in Government Act provided for minimal oversight of independent counsel investigations. The only meaningful oversight power was the attorney general's authority to fire the independent counsel in a narrow set of circumstances with approval from the Special Division. ${ }^{178}$ The current regulations grant the attorney general more oversight power and emphasize that the special counsel is subordinate to the attorney general. ${ }^{179}$ However, even when the attorney general does not tamper in special counsel investigations, the present system creates the potential that the public might perceive the investigations as unfair and biased.

\section{Ethics in Government Act}

Oversight represented one of the biggest challenges to legislators following the Watergate scandal. Congress knew it needed to prevent another incident like the Saturday Night Massacre, but some members feared that an office with too much autonomy could lead to unrestrained, politically-charged investigations that exceeded their original mandates. ${ }^{180}$ The Ethics in Government Act did not create a completely unfettered independent counsel, but there was effectively only one check on the investigations: the attorney general's ability-with approval of the Special Division-to dismiss independent counsels for "good cause" or a condition, such as a health problem, that substantially impaired the independent counsel's performance. ${ }^{181}$ The Act largely succeeded in preventing interference from the executive branch, but concerns about excessive autonomy came to be widely held by members of Congress. In just two decades, Congress fully reversed its position. It went from fearing the executive branch would unjustly interfere with the duties of an independent counsels to handing power back to the executive branch to craft rules for the investigations.

\section{Current Department of Justice Regulations}

Under the current DOJ regulations, the special counsel remains subject to all DOJ rules, regulations, and procedures and answers directly to the attorney general. ${ }^{182} \mathrm{~A}$ special counsel is "not subject to day-to-day supervision," but the attorney general has the right to request an explanation for any investigative or procedural step. ${ }^{183}$ The attorney general can direct the special counsel not to take a proposed action if the attorney general believes it is inappropriate

\footnotetext{
178 See BROWN \& Cole, supra note 84, at 6-7.

17928 C.F.R. § 600.6 (1999).

180 Hearings on H.J. Res. 784 and H.R. 10937 Before the Subcomm. on Criminal Justice of the House Comm. on the Judiciary, 93d Cong. 110, 188 (1973).

${ }^{181}$ See 28 U.S.C. § 595(d) (1994).

18228 C.F.R. § 600.7(a) (1999).

18328 C.F.R. § 600.7(b) (1999).
}

\section{Democracy Clinic}


or unwarranted, but the attorney general must report such a decision to Congress. ${ }^{184}$ These provisions provide safeguards against a runaway special counsel while offering some assurance that the attorney general cannot divert the course of the investigation without detection by Congress.

\section{Recommendation}

We recommend keeping primary oversight of special counsel investigations with the attorney general. As the special counsel's superior and head of the DOJ, the attorney general is in the best position to oversee and provide resources to special counsel investigations. Our proposed statute would retain the rules for oversight in the current regulations, including the requirement that the attorney general report to Congress whenever he or she prevents the special counsel from taking an action. There have not been reports of significant interference by the attorney general in the investigations conducted under the current regulations. $A$ compromised attorney general could certainly affect the course of an investigation by tampering with its budget. Accordingly, our proposal would require that the special counsel's budget be periodically reported to Congress, which would put political pressure on the attorney general to give the Special Counsel's Office the resources it needs.

Congress should not be granted new powers to oversee special counsel investigations. Overseeing criminal investigation is within the purview of the executive branch. Additionally, leaving oversight to the DOJ helps preserve the confidentiality of investigations; information leaks might be more likely with direct congressional involvement. Further, Congress retains its own considerable investigative powers, as seen during the Watergate investigation. ${ }^{185}$ Giving Congress oversight of both avenues of investigation could result in duplicative efforts and limit the effectiveness of special counsel investigations.

\section{E. Removal}

The procedures for removing special counsels are intensely debated. Traditionally, the president has broad discretion to remove officers charged with carrying out the duties of the chief executive. ${ }^{186}$ However, there are obvious concerns that misuse of the removal power could prevent meaningful investigations into executive branch officials. As discussed, the Supreme Court weighed these considerations in Morrison, ${ }^{187}$ concluding that a special

\footnotetext{
$184 / d$.

185 John Dean, The Nixon Defense: What He Knew and When He Knew It 415-16 (2014) (describing author's testimony before Congress revealing his belief that conversations in the Oval Office had been taped, information that would prove critical to the Watergate investigation).

186 See Myers v. United States, 272 U.S. 52, 172 (1926).

187 Morrison v. Olson, 487 U.S. 654 (1988).
}

\section{Democracy Clinic}


prosecutor under the Ethics in Government Act was an inferior rather than a principal officer. ${ }^{188}$ Chief Justice William Rehnquist's opinion for the Court took a functionalist view, reasoning that the attorney general's power to remove an independent counsel and the independent counsel's limited duties, scope of jurisdiction, and tenure indicated that the position was one of an inferior officer. ${ }^{189}$ This meant that an independent counsel could be appointed or removed by individuals other than the president under the Appointments Clause. ${ }^{190}$ Although the Court has never overruled Morrison, subsequent decisions have called its validity into question. ${ }^{191}$ The Supreme Court has not ruled specifically on the constitutionality of the DOJ's special counsel regulations, but similar challenges may arise under the Appointments Clause and the separation of powers doctrine.

Aside from legal protections, political considerations might provide a powerful deterrent against improper removal of a special counsel. In most cases, a special counsel will be selected specifically because an investigation is politically contentious. Even if an attorney general could fire a special counsel, it might have ruinous political consequences. The optics of removing a special counsel investigating high-level executive officers provides the political opponents with devastating fodder to inflame public opinion. ${ }^{192}$ Such a political firestorm occurred after the Saturday Night Massacre. ${ }^{193}$ The incident serves as a reminder to future presidents to refrain from similar tactics. Indeed, despite Trump's frequent attacks, Special Counsel Mueller completed his investigation. ${ }^{194}$ But it is likely that Trump's frequent use of Twitter to attack Mueller was an effort to influence the investigation or galvanize public support in his favor, as opposed to Nixon's more direct approach. ${ }^{195}$

As history demonstrates, the power to remove a special counsel must be carefully considered. A special counsel who could be easily removed might be ineffective in rooting out government corruption and misconduct. Although it is possible that political pressure will deter arbitrary or malicious use of the removal power, relying solely on that possibility leaves the special counsel in a precarious position. A politically savvy president or attorney general may be able to avoid major political ramifications by advancing a misleading explanation for removing a special

188 Id. at 671.

189 Id. at 671-72.

190 U.S. CONST. art. II, § 2, cl. 2.

191 See, e.g., Free Enter. Fund v. Pub. Accounting Oversight Bd., 561 U.S. 477 (2010); Edmond v. United States, 520 U.S. 651 (1997).

192 See Jennifer Hansler, Graham: Trump Firing Mueller Would Be 'the Beginning of the End of His Presidency', CNN (Mar. 18, 2018, 11:00 AM), https://www.cnn.com/2018/03/18/politics/lindsey-graham-mueller-probecnntv/index.html.

193 See supra Part I.C.

194 See supra Part I.D.

195 See, e.g., Donald J. Trump (@realDonaldTrump), TwITTER (Aug. 1, 2018, 9:24 AM), https://twitter.com/realDonaldTrump/status/1024646945640525826; Donald J. Trump (@realDonaldTrump), TWITTER (Mar. 17, 2018, 8:12 PM), https://twitter.com/realDonaldTrump/status/975163071361683456.

\section{Democracy Clinic}


counsel. On the other hand, the limited removal power under the Ethics in Government Act was perhaps the key factor in Congress' decision to allow the statute to expire. ${ }^{196}$ An appropriate legal mechanism for removal must exist that takes into account the lessons of past investigations. The president and, by extension, the executive branch have the responsibility to ensure that the "laws be faithfully executed." 197 Accordingly, the executive branch must be able to remove an executive branch official who impedes this duty. At the same time, a special counsel must be able to carry out investigations without improper interference.

\section{Ethics in Government Act}

Under the Ethics in Government Act, the attorney general could remove an independent counsel for "good cause." 198 If the attorney general chose to do so, he or she would have to notify the Special Division as well as the judiciary committees of both houses of Congress, providing the reasons for removal. If removed, an independent counsel could challenge the decision in court for failing to meet the "good cause" requirement. ${ }^{199}$

\section{Current Department of Justice Regulations}

Current DOJ guidelines resemble the Ethics in Government Act provisions on removal in many ways, but there are several notable differences. An attorney general still must show "good cause" to remove a special counsel. ${ }^{200}$ Unlike the Ethics in Government Act, the regulations provide examples of "good cause," such as "misconduct, dereliction of duty, incapacity, conflict of interest" or violating department policy. ${ }^{201}$ While the attorney general must provide Congress with an explanation of his or her decision, the regulations do not envision judicial review of removal decisions. It is possible that a politically motivated attorney general could bypass the good cause requirement by rescinding the special counsel regulations. The attorney general has this power because the regulations were promulgated under the attorney general's authority and, therefore, are subject to change at his or her discretion. ${ }^{202}$ In such a scenario, a special counsel likely would not have grounds to challenge a termination decision in court.

\section{Recommendation}

Removal procedures must comply with the ambiguous standards set by the Supreme Court. Morrison held that requiring "good cause" for removal does not violate the principle of

\footnotetext{
196 See supra Part I.C.

197 U.S. CONST. art. II, § 3, cl. 5.

198 Levin \& Bean, supra note 58 , at 11, 15.

199 See Brown \& COLE, supra note 84, at 28.

20028 C.F.R. $\S 600.7$ (d) (1999).

201 Id.

${ }^{202}$ See supra Part I.D.
}

\section{Democracy Clinic}


separation of powers because a special prosecutor is an inferior officer. ${ }^{203}$ While Morrison has been criticized in the years since it was decided, it has never been overruled. ${ }^{204}$ Our recommendations assume that Morrison is still good law, notwithstanding some speculation that the current Court may view the issue differently than in years past. ${ }^{205}$

The attorney general should retain the authority to remove a special counsel for cause. As the supervisor of the special counsel's work, the attorney general is in the best position to judge whether there is good cause for removal. Special counsels should receive the protection of a "good cause" removal standard because the nature of their investigations might pressure an attorney general to remove them for reasons other than their performance. "Good cause" removal is appropriate to ensure that the conflicts of interest that necessitated the appointment of a special counsel cannot influence the investigation. This standard properly strikes a balance between protecting the integrity of investigations and allowing for the removal of a special counsel who fails to fulfill the office's duties.

The attorney general's authority to remove a special counsel should also be conditioned upon approval from the Special Division of the judiciary responsible for appointment. ${ }^{206}$ To remove a special counsel, the attorney general would petition the panel with the grounds for removal. The Special Division would then determine if the reasons offered for dismissal satisfied the good cause standard. If the Special Division agreed that removal was justified, the special counsel's removal would be effective and the attorney general could nominate a new special counsel subject to the Special Division's approval. This design remedies one of the primary flaws with the current regulations: the lack of a way to challenge an attorney general's removal decision. By requiring an attorney general to preemptively justify his or her decision, this provision would prevent pretextual claims of good cause from prevailing. Importantly, this process preserves the autonomy of the attorney general when removal is warranted. Involving the judiciary would also hopefully alleviate political backlash against an attorney general who made a valid removal decision in the midst of a divisive investigation.

Although it is unorthodox to subject an attorney general's dismissal of a subordinate to court approval, it is likely constitutional. The strongest argument against such a system is that it

203 Morrison v. Olson, 487 U.S. 654, 697 (1988).

${ }^{204}$ See generally Nick Bravin, Note, Is Morrison v. Olson Still Good Law? The Court's New Appointments Clause Jurisprudence, 98 Colum. L. Rev. 1103 (1998); Lee S. Liberman, Morrison v. Olson: A Formalistic Perspective on Why the Court Was Wrong, 38 AM. U. L. Rev. 313 (1989).

${ }^{205}$ Although Justice Antonin Scalia was the lone dissenter in Morrison in 1988, the Court has shifted substantially since then. Justice Brett Kavanaugh, who worked on the Whitewater investigation, has advocated for changes to the special prosecutor system. See generally Brett M. Kavanaugh, The President and the Independent Counsel, 86 GEO. L.J. 2133 (1998). In particular, he proposed that the president should have the sole power to appoint and remove special counsels. Id. at 2146. This would give a special counsel the powers of a principal officer, but also mandate that the president have the power to remove a special counsel at will.

${ }^{206}$ See supra Part II.B.3.

\section{Democracy Clinic}


would violate the principle of separation of powers by allowing the courts some control over law enforcement, a traditionally executive function. ${ }^{207}$ However, Morrison already rejected this argument as it pertained to the Ethics and Government Act. ${ }^{208}$ The only difference between our proposed removal process and the scheme that Morrison approved is the requirement of preemptive court approval of a removal decision. This difference should not change the legal analysis because the attorney general would still have control over the decision; the Special Division would only review it to ensure that there was good cause. Court approval is required for certain law enforcement actions. Local police must seek a court approved warrant before conducting searches of an individual's property and the DOJ must convince the Foreign Intelligence Surveillance Court that FBI surveillance in certain cases is appropriate before any surveillance can begin. ${ }^{209}$ In a case where the impartiality of the DOJ is questioned, calling upon another branch to safeguard the veracity of the process is prudent. Undoubtedly, the independence of each branch is vitally important, but the Supreme Court does not require that the branches operate in complete isolation from each other. ${ }^{210}$ To create a workable system of government, sometimes the roles of the various branches must overlap.

Supreme Court precedent since Morrison is also consistent with these changes. In Edmond $v$. United States, ${ }^{211}$ the Court took a more formalistic view of analysis under the Appointments Clause than it had in Morrison. Nevertheless, Justice Scalia's view that an inferior officer is someone supervised by a principal officer is consistent with the special counsel system. ${ }^{212}$ The attorney general continues to supervise the special counsel throughout the process. Free Enterprise Fund v. Public Company Accounting Oversight Board does not present any problems for the proposal either. ${ }^{213}$ There, the Court invalidated an agency design that guarded both an inferior officer and their supervisors with for cause protections. ${ }^{214}$ There is only one level of for cause protection in this design, considering that the president can remove the attorney general at will. ${ }^{215}$ Thus, the "[m]atryoshka doll of tenure protections" that the Court feared is inapplicable to the special counsel process. ${ }^{216}$

\footnotetext{
207 See U.S. CONST. art. II, § 3, cl. 5.

208 See Morrison, 487 U.S. at 693-96.

${ }^{209}$ See 50 U.S.C. $§ 1881$ (a) (2018).

210 See Morrison, 487 U.S. at 693-94; Video Interview with William M. Treanor, supra note 124.

211520 U.S. 651 (1997).

212 Id. at 663.

${ }^{213} 561$ U.S. 477 (2010).

214 Id. at 495.

215 Id. at 492.

216 Id. at 497.
}

\section{Democracy Clinic}




\section{F. Termination}

It is critical to have clear procedures for ending special counsel investigations. Without transparency and accountability, investigations might come to an end prematurely.

\section{Ethics in Government Act}

Under the Ethics in Government Act, the independent counsel or the Special Division could terminate an investigation. ${ }^{217}$ If the independent counsel triggered the termination, he or she was required to notify the attorney general that the investigation was complete. ${ }^{218}$ The Special Division could terminate an investigation when it determined that the investigation was sufficient or at a stage where the DOJ could complete it through traditional channels. ${ }^{219}$ The Special Division could terminate the investigation in response to a recommendation from the attorney general. ${ }^{220}$

The Ethics in Government Act's termination procedures protected against both interference by the executive branch and runaway independent counsel investigations. By permitting the attorney general to recommend termination, the process allowed the executive branch to end investigations, as long as the Special Division agreed that it was justified. Procedures for terminating independent counsel investigations without the consent of the impendent counsel provided protection against limitless and unrestrained investigations.

\section{Current Department of Justice Regulations}

Under the current DOJ regulations, the attorney general and the special counsel have the authority to terminate investigations. ${ }^{221}$ There is no established timeline for a special counsel investigation's length, but a special counsel is required to annually report the status of his or her investigation and send budget requests to the attorney general. ${ }^{222}$ Upon review, the attorney general can decide whether an investigation should continue and whether the budget requested is appropriate. ${ }^{223}$ Under this system, decisions made by the attorney general regarding the termination of an investigation may go unchecked, and the attorney general could effectively terminate an investigation by withholding necessary funds.

21728 U.S.C. § 596(b)(1)-(2) (1994).

${ }^{218}$ BROWN \& COLE, supra note 84 , at 7.

219 Id.

220 Id.

22128 C.F.R. $\S 600.7(d)$ (1999).

22228 C.F.R. $\S 600.8$ (1999).

223 Id.

\section{Democracy Clinic}




\section{Recommendation}

We recommend using the Ethics in Government Act's approach to termination. Termination of an investigation should be triggered either by the special counsel or by the attorney general with consent from the Special Division. The Special Division would give the attorney general deference in his or her decision, and would withhold approval only in extreme cases, such as where there is evidence that the attorney general's decision is attempting to obstruct the investigation. Investigations should not have formal timelines or end dates. While there is a legitimate concern about runaway investigations and their expense, timelines and end dates could encourage obstruction from witnesses or those under investigation, who may attempt to run out the clock on an investigation rather than cooperate.

\section{G. Release of Findings}

Special counsels have typically prepared reports summarizing their offices' work and the findings of their investigations. It is critical that the release of findings proceeds smoothly and that the reports are concise and comprehensible to foster public trust. Both the Ethics in Government Act and the current DOJ regulations capture parts of what is necessary concerning the release of findings, but neither has proven wholly effective.

\section{Ethics in Government Act}

Under the Ethics in Government Act, at the termination of an investigation, the independent counsel was mandated to complete a report and submit it to the Special Division. ${ }^{224}$ The report detailed the independent counsel's work throughout the investigation, including descriptions of any prosecutions the office brought. ${ }^{225}$ Additionally, the Ethics in Government Act directed the independent counsel to "advise the House of Representatives of any substantial and credible information which such independent counsel receives, in carrying out the independent counsel's responsibilities under this chapter, that may constitute grounds for an impeachment." 226 Independent Counsel Starr provided his report regarding President Clinton to Congress under the latter provision. ${ }^{227}$ Critics asserted that the report went into excessive detail about Clinton's sexual relationship with Monica Lewinski. ${ }^{228}$

\footnotetext{
224 BROWN \& COLE, supra note 84 , at 7.

225 Id.

22628 U.S.C. $§ 595$ (c) (1994).

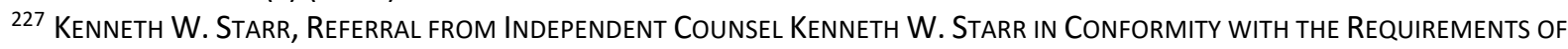
Title 28 United States Code, Section 595(c), H.R. Doc. No. 105-310 (1998).

${ }^{228}$ Video Interview with William M. Treanor, supra note 124; Video Interview with Mark H. Tuohey, supra note 124.
}

\section{Democracy Clinic}




\section{Current Department of Justice Regulations}

Under the current DOJ regulations, a special counsel is required to submit a report to the attorney general at the conclusion of the investigation. ${ }^{229}$ This report is confidential, and the regulations do not provide for its disclosure to the public. The report must detail the special counsel's reasoning for decisions made and methods used throughout the investigation, as well as any prosecutorial decisions. ${ }^{230}$ After receiving the special counsel's report, the attorney general is required to send his or her own report to the chairs and ranking members of the Senate and House Judiciary Committees. ${ }^{231}$ The attorney general's report must include "an explanation for each action" taken and detail any alleged misconduct by the special counsel. ${ }^{232}$

The regulations do not mandate that the DOJ publicly disclose any information about the special counsel's findings or any version of the report to members of Congress. However, the regulations do provide that the attorney general may release the report if he or she deems doing so to be in the public interest. ${ }^{233}$ The regulations provide the attorney general discretion to keep the report from Congress and the public when necessary, such as when it includes information about sensitive matters of national security, foreign relations, or ongoing investigations. However, the expansive control that the attorney general retains might be subject to abuse. Even members of Congress may never receive the special counsel's full report-only the attorney general's abbreviated summary. This process allows for the possibility of deliberate mischaracterizations of a special counsel's findings. For example, Attorney General Barr's handling of the Mueller report faced criticism for obscuring and misrepresenting the substance of Mueller's findings. ${ }^{234}$

\section{Recommendation}

A special counsel should submit a report on the investigation directly to Congress, namely the chairs and ranking members of both chambers' judiciary committees, without the attorney general's involvement. This would allow the special counsel's findings and conclusions to reach a bipartisan group of lawmakers, who are in a position to act on information in the report if they deem it necessary. It is also consistent with Congress' constitutionally implied oversight powers. ${ }^{235}$

\footnotetext{
22928 C.F.R. $§ 600.2$ (1999).

230 Id.

231 Id.

23228 C.F.R. § 600.9(a) (1999).

23328 C.F.R. $\S 600$ (1999).

${ }^{234}$ Video Interview with Mark H. Tuohey, supra note 124.

${ }^{235}$ See U.S. CONST. art. I, § 8, cl. 18.
}

\section{Democracy Clinic}


Given that the attorney general would not oversee the release of information about special counsel investigations, it is imperative to set clear standards for reporting to ensure both fairness and propriety. Accordingly, the report should focus only on federal crimes that the special counsel uncovered. The report should include clear statements of what crimes the special counsel concluded were committed, including by the president. While Special Counsel Mueller believed he was prohibited from making such a pronouncement about the president due to the Office of Legal Counsel memorandum that asserts that the president is immune from criminal indictment while in office, we believe that a clear statement on criminality is permissible and necessary. Though this raises questions of fairness due to the president's inability to present a defense in court, the statement does not deprive the president of his or her liberty. Additionally, the president has a unique and extremely prominent platform to defend himself or herself. ${ }^{236}$ Finally, the special counsel's report should include an executive summary containing key findings and conclusions. This summary must be clear, concise, and comprehensible, but should consist of narrative detail of the investigation, going beyond a general statement. This will allow Congress and the public at large (if it is released to them), to understand the key takeaways of the investigations.

\section{Conclusion}

To create a fair and effective system for investigating the executive branch, the rules for special counsel regulations must balance independence and accountability. While prosecutorial and law enforcement responsibilities have traditionally fallen within the purview of the executive branch, there are times when those powers must be shared with other branches to ensure impartial investigations of certain government officials. Accordingly, our recommendations seek to address that balance by dividing power and decision-making between the attorney general and Special Division of the federal judiciary, while providing Congress means of sufficient oversight.

${ }^{236}$ See U.S. CONST. amend. V.

\section{Democracy Clinic}

